All or part of this document may be freely reproduced with acknowledgment of the source "Dialogue between judges, European Court of Human Rights, Council of Europe, 2014"

(C) European Court of Human Rights, 2014

(C) Photos: Council of Europe 


\section{Dialogue between judges}

Proceedings of the Seminar 31 January 2014

"Implementation of the judgments of the European Court of Human Rights: a shared judicial responsibility?"

Strasbourg, January 2014 


\section{TABLE OF CONTENTS}

\section{Proceedings of the Seminar \\ "Implementation of the judgments of the European Court of Human Rights: a shared judicial responsibility?"}

Dean Spielmann

President of the European Court of Human Rights

Julia Laffranque

Judge of the European Court of Human Rights

Antônio Augusto Cançado Trindade

Judge of the International Court of Justice, The Hague

Linos-Alexandre Sicilianos

Judge of the European Court of Human Rights

\section{Alec Stone Sweet}

Professor, Yale Law School, United States of America

Mark Villiger

Section President of the European Court of Human Rights

\section{Solemn Hearing} on the occasion of the opening of the judicial year 2014

Dean Spielmann

President of the European Court of Human Rights 


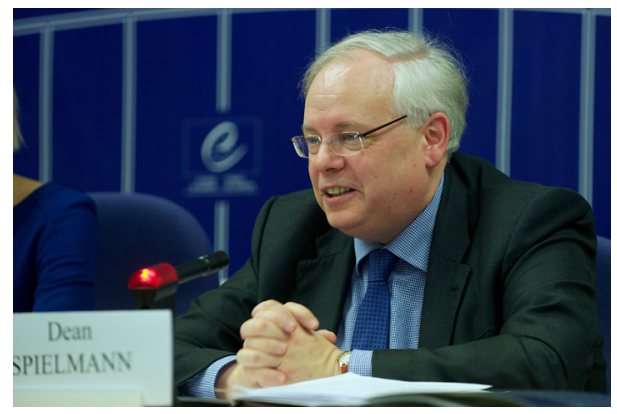

\section{Dean Spielmann}

\section{President of the European Court of Human Rights}

\section{Opening address}

Presidents, Ladies and gentlemen, Dear friends,

First of all, let me say how pleased I am to see so many of you gathered here today for this seminar, which as usual is being held before the Court's solemn hearing. Your attendance is a sign of your interest in this meeting between the European Court of Human Rights and the Supreme Courts of Europe. The presence of senior academics and Government Agents before the Court will, I am sure, also contribute to the interest of the discussions this afternoon.

I should like to thank Judges Raimondi, Bianku, Nußberger, Sicilianos and Laffranque, who have organised the seminar with the assistance of Roderick Liddell.

I also wish, of course, to welcome our two speakers: Antônio Cançado Trindade, Judge of the International Court of Justice and a long-standing friend, and Alec Stone Sweet, Professor at Yale Law School, whom we are pleased to be welcoming for the first time.

The theme chosen this year, "Implementation of the judgments of the European Court of Human Rights: a shared judicial responsibility?", is particularly important in my view and the title seems extremely apt. As I am sure you will understand, this is a highly topical theme.

In his remarkable article written on the occasion of the $60^{\text {th }}$ anniversary of the entry into force of the Convention, Nicolas Hervieu, who I know is among us today, emphasised that the institutional system set up by the Convention had remained in constant motion, adding that our Court had become - and I quote - the "centre of gravity of human rights in Europe".

Thank you for this fine phrase, but if we want it to remain true, our judgments will need to be properly executed.

Of course, it is not necessarily easy to execute a judgment of our Court, and the excellent paper produced by the seminar's organising committee provides a comprehensive overview of the question of the execution of our judgments since the system came into being. It also shows how our Court, which in theory played no role in the execution of its judgments, has over the years had to introduce procedures such as pilot judgments to ensure that its decisions are executed.

The background paper is also interesting in that it provides a clear indication of how the national courts, despite various initial reservations, have over the course of time become partners in the implementation of our judgments. This process, to my mind, is now operating relatively smoothly. A dialogue has built up between us as a result of this shared judicial responsibility which I fervently wish for.

Protocol No. 16, once it is in force, will clearly strengthen this dialogue. However, if I may, I shall leave this subject aside for now as I am intending to touch on it in my speech this evening.

Being experts on the Convention, you will also be aware that as far as the execution of certain of its judgments is concerned, the Court has for a while now been experiencing some turbulence. At this time, the Court needs its friends all the more. And I know that you are among them. 
Without wishing to give away too much of my speech this evening, I can tell you now that the judgments I have chosen to highlight for 2013 are closely linked to the theme you will be discussing today.

Before I leave you, I would just like to invite you after the seminar to the presentation of the volume of studies in honour of our friend, the former Russian judge Anatoly Kovler. This short ceremony will take place in the entrance hall. I would add that there will be a table in the entrance hall with copies of all the publications produced by Wolf Legal Publishers in conjunction with the Court.

I have already spoken for too long, so I will now give the floor immediately to my colleague and friend Julia Laffranque, who has very kindly agreed to chair this seminar.

Thank you for your attention. 


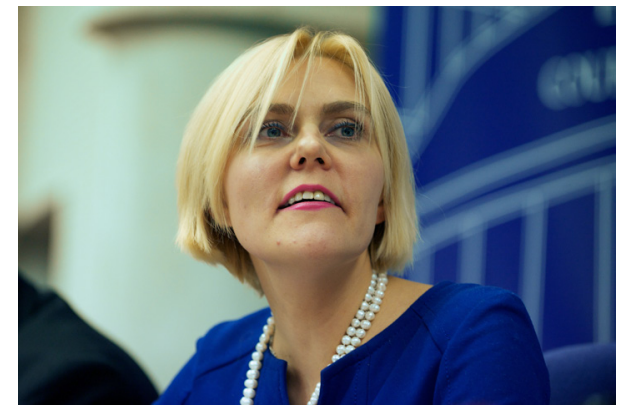

\title{
Julia Laffranque
}

\author{
Judge of the \\ European Court of Human Rights
}

President, senior members of the judiciary, Ladies and Gentlemen, dear colleagues,

Another year has passed and here we are again in Strasbourg for the tenth seminar marking the official opening of the judicial year of the European Court of Human Rights ("the Court"). This seminar is an opportunity for us all to exchange views and swap experiences on our shared responsibility: the protection of human rights. One morning recently my five year old son said to me: "Mum, we mustn't forget the humans!". Every day I remember this and every day we all, as judges, attempt to carry on our profession to the best of our ability, a task which, to quote Anatole France, consists in "combining a philosophical mindset with simple goodness".

But is that enough? Do we give sufficient consideration to what happens after we deliver our judgments? According to our Court's consistent case-law, the Convention is intended to guarantee rights that are not theoretical or illusory, but practical and effective. The right of petition would be illusory if a final and binding judicial decision were allowed to remain inoperative. This is equally true of international systems, despite the fact that the national courts have more wide-ranging powers when it comes to applying and enforcing judgments than those conferred on the Court by the Convention, and the fact that in democratic States governed by the rule of law the execution of domestic judgments should be self-evident and should not require the intervention of the courts.

The Committee of Ministers of the Council of Europe has recognised the vital importance of speedy and effective execution of the Court's judgments for the credibility and efficacy of the Convention as a constitutional instrument of the European public order on which the democratic stability of the continent depends. Each of the three high-level conferences on the future of the Court, which took place respectively in Interlaken (February 2010), Izmir (April 2011) and Brighton (April 2012), acknowledged the fundamental importance of execution for the effectiveness of the Convention system. So how can we ensure that the judgments of the European Court of Human Rights are implemented? Is it a matter of shared judicial responsibility between the States Parties and the national courts on the one hand and the Court on the other? Our seminar today will attempt to answer that question.

Ladies and gentlemen, I would like to draw your attention to some changes in the structure of this year's seminar, which is entitled "Implementation of the judgments of the European Court of Human Rights: a shared judicial responsibility?"

First of all, this topic can be approached from two different angles, depending on whether one adopts the standpoint of the Court or of the national judicial systems: the discussion will therefore focus firstly on the role of an international court in the implementation of its own judgments, its powers and the limits of those powers, and secondly on the role of the national courts in implementation of the Court's judgments.

To discuss these two sub-topics, we have invited two keynote speakers: Judge Antônio A. Cançado Trindade and Professor Alec Stone Sweet.

The other new feature consists in having two judges of the Court comment on each of these topics and thus present Strasbourg's perspective. At today's seminar, Judge Linos-Alexandre 
Sicilianos and Judge Mark Villiger, President of the Fifth Section, will be doing the honours. I hope that this new approach will facilitate the discussion and contribute to a rich and dynamic debate on the topics before us. I would also like to point out that, for the first time, all the participants received, together with their invitation, a folder containing information on the background paper prepared by the organising committee, made up of Judges Guido Raimondi, Ledi Bianku, Angelika Nußberger, Linos-Alexandre Sicilianos, myself and Roderick Liddell from the Registry. This paper has already been posted on the Court's Internet site in the two official languages and is also in your folder. As a result, each participant is better equipped to take an active part in the seminar. Needless to say, our organising committee is open to all suggestions, whether about possible topics for discussion at future seminars or about the working methods of these seminars.

To return to our main topic, there is no denying that our situation is one in which a delicate balance has to be struck between the jurisdiction of the international judge and national sovereignty. This subject has been the source of much debate. In September 2013 Professor Anja Seibert-Fohr and Judge Mark Villiger organised a top-level conference on this topic at the University of Göttingen. One of the crucial issues in the relationship between the Court and the national authorities is the principle of subsidiarity, as emphasised by the new Protocol No. 15 to the Convention. This principle also imposes obligations on States and on their courts as regards the execution of the Court's judgments.

The mechanism for the execution of the Court's judgments is set out in Article 46 of the Convention, which provides firstly that those judgments are binding on the respondent States and secondly that their execution is subject to the supervision of the Committee of Ministers. States enjoy quite a broad discretion when it comes to executing judgments. In practice, the Court has become more proactive with regard to the execution of its own judgments than it was when it delivered judgments that were largely declaratory. This may be a consequence of the enlargement of the Council of Europe, which raised new issues to which the Court has had to respond by adopting pilot judgments. Perhaps it is also due to the increasing reluctance of the "old democracies" to accept the Court's rulings on certain politically sensitive issues. Moreover, it is commonly accepted that execution entails not only individual measures affording redress to the individual applicant or applicants but also general measures aimed at eliminating the root causes of any violation found by the Court.

Protocol No. 14 to the Convention added two new elements to the execution process, by allowing the Committee of Ministers to seek a ruling from the Court on the interpretation of a judgment or its execution by the respondent State. In both cases the Committee of Ministers' decision requires a two-thirds majority. To date, the Committee of Ministers has not made use of this new possibility. The mechanism is different under European Union law: if the Court of Justice finds that the Member State concerned has not complied with its judgment it can order it to pay a lump sum or impose a penalty payment.

Our seminar will focus above all on the dialogue between judges in the implementation of the Court's judgments, without addressing in detail the role played by the Committee of Ministers in this sphere. This dialogue can be seen as an interaction between the Court and the national courts under the terms of Protocol No. 16 to the Convention, the preamble to which states that "the extension of the Court's competence to give advisory opinions will further enhance the interaction between the Court and national authorities and thereby reinforce implementation of the Convention, in accordance with the principle of subsidiarity". Or, to borrow the expression used by Professor Sabino Cassese, judge of the Italian Constitutional Court, the "interchange between judges".

This interaction, interchange, or interplay as you may wish to call it between the national authorities, including national judiciaries, and the Court is to my mind of prime importance for the effective enforcement of the Court's judgments. I will concentrate on the national judiciaries since this is the main focus of our seminar, especially the second half of it. It would be nice to think that national judges are also European human rights judges in their respective countries, and they certainly need to feel so, especially when dealing with the facts and national law, where the Court cannot and should not act as a fourth-instance court. The key to successful interaction lies in mutual trust and respect. This trust finds its normal, and not hierarchical, limits in the European supervision by the Court of how the national authorities and domestic courts have applied the Convention and upheld 
its values. In exercising this supervision it is important for the Court to take into account the whole picture of the country's legal system and to give orientation and guidance to the State, leaving to the national authorities the final choice as to the methods to be used to achieve the Conventioncompatible goal, and respecting the division of powers both at national level and between the Court and the Committee of Ministers.

However, in the context of the Court's case-law the question has been raised whether the Court has the power to prescribe in the operative part how exactly the State is to redress the violation. Another set of questions relates to the issue of the reopening of proceedings at national level after a violation has been found by the Strasbourg Court. Is reopening, in those countries where it is possible, the most appropriate way of achieving restitutio in integrum - a principle of international law on which the Court has been relying? A more far-reaching issue remains as to what are the true effects of the Court's judgments.

On the basis of comparative study and practice it seems that the domestic courts are best placed to act as ambassadors for the Court's case-law in the Contracting States. The burden and responsibilities of judiciaries all over Europe are significant and, because the national courts also implement the judgments of our Court, the need for them to understand the Strasbourg Court's judgments and accept them is the crucial element. That is why our judgments have to be well and justly reasoned, be clear and consistent, widely disseminated and translated, both literally and figuratively, into the domestic legal order.

Thank you, and let us now move on to the first sub-topic of the seminar. 


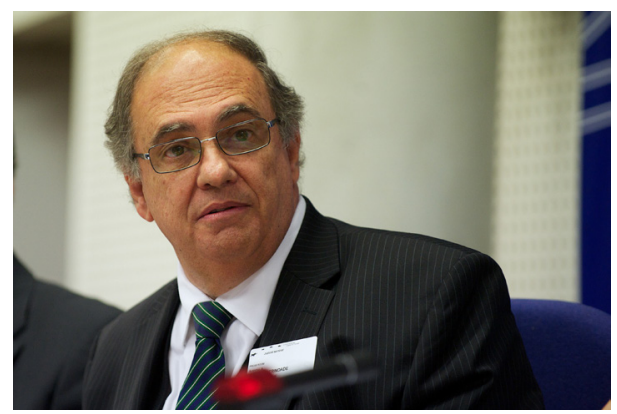

\title{
Antônio Augusto Cançado Trindade
}

\author{
Former President of the Inter-American Court of \\ Human Rights; \\ Judge of the International Court of Justice; \\ Emeritus Professor of International Law \\ of the University of Brasilia, Brazil
}

\section{Compliance with judgments and decisions - The experience of the Inter- American court of Human Rights: a reassessment}

\section{PRELIMINARY OBSERVATIONS}

1. It is a source of great satisfaction to me to be able to participate in this seminar of the European Court of Human Rights (ECHHR): it affords me the opportunity to reiterate the expression of my links of affection with the Court, which go back to the early seventies. I have a clear and positive recollection of the two previous occasions when I took the floor here, namely at the ceremony to mark the opening of the 2004 judicial year, under the Presidency of Judge Luzius Wildhaber, and then at the first joint meeting of the three international human rights courts (the ECtHR, the Inter-American Court of Human Rights (IACtHR) and the African Court on Human and Peoples' Rights) in 2008, under the Presidency of Judge Jean Paul Costa. It is a great pleasure for me to come back to the siège of the ECtHR, now under the Presidency of Judge Dean Spielmann, to participate in the present seminar on a subject of great relevance and topicality - the implementation of the judgments of the European Court of Human Rights - and to share this panel with Judge Linos-Alexandre Sicilianos.

2. May I start with a note of gratitude to the organisers of this seminar. When I was approached by them and I suggested, as the topic of my contribution, the experience on the matter of the Court's sister institution, the IACtHR, so that lessons could perhaps be drawn from it by my colleagues at the ECtHR in tackling the dilemmas they face today, I was touched by their receptiveness. Having been engaged in the dialogue between international courts for many years, and being a strong believer in it, I wish to express my deep appreciation for the open mindedness of the ECHHR in taking on board the experience of its counterpart court in Latin America regarding the subject matter under discussion in this seminar.

3. To start with it should be observed that, unlike the ECHHR, the IACHHR does not have the benefit of a Committee of Ministers for the implementation of its judgments. Given this gap in the mechanism under the American Convention on Human Rights (ACHR), I considered it appropriate to stress, during my years as President of the IACHHR (1999-2004), the need to establish a permanent mechanism for supervision of the execution of, or compliance with, the judgments and decisions of the IACHHR. In successive Reports which I presented to the main organs of the Organization of American States (OAS), I advanced specific proposals to that effect. In my Report of 17 March.2000, for example, I warned that, in the event of "non compliance with a judgment of the Court, the State concerned incur[red liability for] an additional violation of the Convention" ${ }^{\prime \prime}$.

1 Report presented to the Committee on Juridical and Political Affairs (CAJP) of the Permanent Council of the OAS, reproduced in: A.A. Cançado Trindade, Informe: Bases para un Proyecto de Protocolo a la Convención Americana sobre Derechos Humanos, para Fortalecer Su Mecanismo de Protección, vol. II, 2nd. ed., IACtHR, San José de Costa Rica, 2003, p. 125. 
Despite the attention with which the delegations of member States of the OAS listened to me, the gap has persisted to date. On one particular occasion a respondent State (which had denounced the ACHR), taking advantage of the gap, saw fit not to provide any information at all concerning its compliance with the judgments in the case of Hilaire, Constantine and Benjamin et al. v. Trinidad and Tobago (2001-2002). This omission occurred despite the fact that, as President of the IAC+HR, I had informed the OAS General Assembly (held in Santiago de Chile in 2003) of the failure to comply - just as I had done three years earlier in relation to the Peruvian cases at the 2000 General Assembly in Windsor, Canada, ${ }^{2}$ in conformity with Article 65 of the ACHR.

\section{REFERRAL OF ISSUES OF NON-COMPLIANCE TO THE MAIN ORGANS OF THE OAS}

5. Within the IAC+HR, I constantly stressed the pressing need to have non compliance with judgments by the respondent States (whether partial or total) submitted for the consideration of the competent organs of the OAS, with a view to taking due measures to preserve the integrity of the IACHHR mechanism of protection. Supervision of the execution of IACtHR judgments could not continue to be carried out only once a year, and in a very summary way, by the OAS General Assembly itself.

6. A proposal which I advanced and insisted upon during my Presidency of the IACHHR (1999. 2004) was the creation within the Committee on Juridical and Political Affairs (CAJP) of the OAS of a working group composed of representatives of the States Parties to the ACHR, to be in charge of the supervision on a permanent basis within the OAS of the execution of IACtHR judgments, so as to secure compliance with them and thereby the realisation of justice. ${ }^{3}$ In successive Reports to the main organs of the OAS I stressed the pressing need to provide mechanisms - of both domestic and international law - designed to secure the faithful and full execution of the judgments of the IACtHR at domestic level.

7. The ACHR expressly provides that the part of the judgments of the IACtHR pertaining to compensatory damage may be executed in the State concerned in accordance with the domestic procedure in force for the execution of judgments against the State (Article $68 \S 2$ ); the Convention adds that States Parties are bound to comply with the decisions of the IACtHR in every case to which they are parties (Article $68 \S 1$ of the ACHR). By the end of the last decade, at domestic law level, only two States Parties to the ACHR had actually adopted permanent mechanisms for the execution of international judgments. ${ }^{4}$ Throughout the last decade, five other States Parties have adopted norms relating to execution of the judgments of the IAC+HR. ${ }^{5}$

\section{SUPERVISION OF COMPLIANCE WITH IACTHR JUDGMENTS AND DECISIONS}

8. In the other States, the judgments of the IACHHR continued to be executed on the basis of empirical - or even casuistic - criteria, in the absence of a permanent mechanism under domestic law to that end. Given the absence of legislative or other measures to that effect, in my Tratado de Direito Internacional dos Direitos Humanos I expressed the hope that States Parties would seek to equip themselves so as to secure the faithful execution of the judgments of the IACtHR in their

2 As documented in the OAS General Assembly's 2000 and 2003 Annual Reports.

3 See A.A. Cançado Trindade (2003), Informe: Bases para un Proyecto de Protocolo a la Convención Americana sobre Derechos Humanos..., op. cit. supra no. (1), pp. 47-49, 111, 125, 234-235, 664, 793-795 and 918-921, esp. pp. 793-794.

4 They are, respectively, Peru, which attributes to the highest judicial organ in domestic law (the Supreme Court of Justice) the power to determine the execution of, and compliance with, the decisions of organs of international protection whose jurisdiction Peru has undertaken to recognise (judicial model); and Colombia, which has opted for the attribution to a Committee of Ministers of the same function (executive model).

5 Namely Costa Rica, Guatemala, Brazil, Venezuela and Honduras. Moreover, the duty of compliance with IACtHR judgments and decisions has been expressly acknowledged by the Supreme Courts of a few States Parties: for instance, in 2007, by the Supreme Court of Justice of Argentina and the Peruvian Constitutional Court. Despite these advances, the problem of undue delays in full compliance by respondent States with the IACtHR's judgments and decisions subsists to date. 
domestic legal orders. ${ }^{6}$ And even if a given State Party to the ACHR has adopted a domestic law procedure to this effect, it cannot be inferred that the execution of the judgments of the IACtHR is ipso jure secured within its domestic legal order. Domestic law measures need to be complemented by measures under international law, and particularly by the creation of a permanent mechanism of international supervision of the execution of IACHHR judgments - as I argued throughout my Presidency of that Court (1999-2004).

9. Thus, in my extensive Report of 5 April 2001 in which I presented to the CAJP (of the OAS Permanent Council) the document I had prepared, as rapporteur of the Court, containing the Bases for a Draft Protocol to the American Convention on Human Rights, to Strengthen Its Mechanism of Protection, I proposed the creation of a mechanism of international supervision of IACHHR judgments within the OAS (in the form of a working group of the CAJP), to operate on a permanent basis in order to bridge the gap in the inter-American system of human rights protection. ${ }^{7}$ Such supervision, as I pointed out, is incumbent upon all the States Parties to the ACHR in the exercise of their collective guarantee, so as to give due application to the basic principle of pacta sunt servanda. ${ }^{8}$

10. Subsequently, in my Report of 19 April 2002 to the CAJP of the Permanent Council of the OAS, I reiterated my proposal (which I had submitted for the consideration of the Permanent Council itself and of the General Assembly of the OAS in 2001), aimed at filling a gap in the inter-American system of human rights and thus strengthening the mechanism of protection of the ACHR. ${ }^{9}$ Once again the matter was brought to the attention of the OAS Permanent Council in 2002, and again in 2003. Faced with the inactivity of the OAS in this respect, I returned to the subject with special emphasis in my Report of 16 October 2002 to the Permanent Council of the OAS on The Right of Access to International Justice and the Conditions for Its Realization in the Inter-American System of Protection of Human Rights; on that occasion, I again posited that States Parties are individually bound to comply with the judgments and decisions of the IAC+HR, "as established by Article 68 of the ACHR in application of the principle pacta sunt servanda, and, moreover, as an obligation of their own domestic law". They are likewise jointly bound to guarantee the integrity of the ACHR; "the supervision of the faithful execution of the rulings of the Court is a task that falls upon all the States Parties to the Convention" ..$^{10}$

11. I then observed that the ACHR, in creating obligations for States Parties vis à-vis all persons within their respective jurisdictions, requires the exercise of the collective guarantee for the full realisation of its object and purpose, whereby its mechanism of protection can be enhanced. "The faithful compliance with, or execution of, their judgments is a legitimate preoccupation of all international courts" and is a "special concern" of the IAC+HR. "It so happens that, in general, States Parties have been complying with the rulings concerning reparations in the form of compensatory damages, just satisfaction to the victims and harmonisation of their domestic laws with the provisions of the ACHR; but the same has not happened in respect of the duty to investigate the facts and punish those responsible for grave violations of the human rights which are protected (as the series of cases concerning massacres was to disclose clearly over the last decade). ${ }^{12}$ This remains a cause for concern, as such investigations and sanctions are vital in order to put an end to impunity (with its negative and corrosive consequences for the social fabric as a whole).

6 See A.A. Cançado Trindade (1999), Tratado de Direito Internacional dos Direitos Humanos, vol. II, Porto Alegre/Brazil, S.A. Fabris Ed., p. 184.

7 A.A. Cançado Trindade, Informe: Bases para un Proyecto de Protocolo..., op. cit. supra no. (1), pp. 369. For a recent reassessment of this and other proposals, see A.A. Cançado Trindade (2012), Le Droit international pour la personne humaine, Paris, Pédone, pp. 169-214.

8 Ibid., p. 378.

9 Ibid., pp. 794-795

10 lbid., pp. 919-920.

11 lbid., pp. 919-920.

12 See A.A. Cançado Trindade, The Access of Individuals to International Justice, Oxford, Oxford University Press, 201 1, Chapter X, pp. 179-191 ; A.A. Cançado Trindade (2011), State Responsibility in Cases of Massacres: Contemporary Advances in International Justice, Utrecht, Universiteit Utrecht, pp. 1-71. 
12

Again in my aforementioned Report of 19 April 2002, I observed that, in view of the persisting institutional gap in the inter-American system of protection in this sphere, the IACtHR had taken the initiative of supervising, motu propio, the execution of its judgments in the course of its periods of session. However, this was without prejudice to the collective guarantee - undertaken by all States Parties to the ACHR - to execute faithfully the judgments and decisions of the Court. My proposal to the OAS, which I reiterated, for the creation of a working group of the CAJP to undertake the supervision of compliance with the IACtHR's judgments and decisions on a permanent basis did not, unfortunately, see the light of day. Such a measure was intended to be complemented by measures to be taken by States Parties at the domestic law level; the principle pacta sunt servanda would thus become effective with measures that were to be taken, pari passu, at both international and national levels. ${ }^{13}$

13. The gap persists to date (beginning of 2014). The OAS took note of my proposal in successive resolutions up to the beginning of 2007 . The only point which materialised was another proposal I had made to create a fund of free legal aid to petitioners in need of it. The other points have remained presumably "under study", and the IACHHR continues to assume the additional task of supervising the execution of its judgments in the domestic law of the respondent States, by means of successive resolutions (on State compliance), at times preceded by post-adjudicative public hearings.

14. Earlier examples - and remarkable ones - of compliance with the IACHHR's judgments can be found, for instance, in the cases of Barrios Altos (2001), a cas célèbre on the incompatibility of amnesties with the ACHR, and Loayza Tamayo (1997), both concerning Peru. In the latter, the respondent State complied promptly (on 20 October 1997) with the Court's ruling (judgment of 17 September 1997) by releasing a political prisoner. In the case of Juan Humberto Sánchez v. Honduras (judgment of 7 June 2003), the IACtHR reiterated its own case-law to the effect that acts or omissions in breach of the protected rights can be committed by any branch of the State (executive, legislative or judicial) or by any public authority.

\title{
IV. SUPERVISION MOTU PROPIO BY THE IACTHR ITSELF: THE LEADING CASE OF BAENA-RICARDO ET AL. (270 WORKERS) V. PANAMA, 2003
}

15. The supervision, undertaken motu propio by the IAC+HR, of the execution of its judgments has occurred in successive cases in recent years. As a pertinent illustration, may I again point to the leading case of Baena-Ricardo et al. (270 workers) v. Panama (see above). In its memorable judgment (of 28 November 2003) on its competence to supervise compliance with its previous judgment in that case (judgment of 2 February 2001 on Merits and reparations), the IAC+HR determined that

\begin{abstract}
"... jurisdiction includes the authority to administer justice; it is not restricted to stating the law, but also encompasses monitoring compliance with what has been decided. ... Monitoring compliance with judgments is one of the elements that comprises jurisdiction. ... Compliance with the reparations ordered by the Court in its decisions is the materialization of justice for the specific case and, ultimately, of jurisdiction.
\end{abstract}

Compliance with judgment is strongly related to the right to access to justice, which is embodied in Articles 8 (Right to a Fair Trial) and 25 (Judicial Protection) of the American Convention" (paragraphs 72-74).

16. The IACHHR lucidly added, in the same vein, that to guarantee the right of access to justice it was not sufficient for a final ruling to be delivered declaring rights and obligations and extending protection to the persons concerned. It was also necessary to benefit from the existence of

"...effective mechanisms to execute the decisions or judgments, so that the declared rights are protected effectively. The execution of such decisions and judgments should be considered an integral part of the right to access to justice, understood in its broadest sense, as also

13 Ibid., pp. 919-921 
encompassing full compliance with the respective decision. The contrary would imply the denial of this right.

... If the responsible State does not execute the measures of reparations ordered by the Court at the domestic level, it is denying the right to access to international justice" (paragraphs 82-83).

17. Next, in the same judgment on competence in the case of Baena-Ricardo et al. (270 workers) v. Panama (see above), the IACHHR, to my particular satisfaction, endorsed the understanding that I had expressed in my concurring opinion concerning its Advisory Opinion no. 18 (of 17 September 2003) on the Juridical Condition and Rights of Undocumented Migrants, even expressly citing my Individual Opinion (no. 70) ${ }^{14}$ to the effect that the competence of the IACHR to supervise the execution of its judgments was grounded on its "constant and uniform practice" (bearing in mind Articles 33, 62 (1) and (3) and 65 of the ACHR, and Article 30 of the Statute) and the "resulting opinio juris communis of the States Parties to the Convention" (reflected in several resolutions on their compliance with the IACHHR's judgments). The IACHHR added, echoing my own views on the universal juridical conscience as the ultimate material source of international law and of all law ${ }^{15}$ (see below):

"The opinio juris communis means the expression of the universal juridical conscience ${ }^{16}$ through the observance, by most of the members of the international community, of a determined practice because it is obligatory. This opinio juris communis has been revealed because these States have shown a general and repeated attitude of accepting the monitoring function of the Court, which has been clearly and amply demonstrated by their presentation of the reports that the Court has asked for, and also their compliance with the decisions of the Court when giving them instructions or clarifying aspects on which there is a dispute between the parties regarding compliance with reparations" (paragraph 102). ${ }^{17}$

18. In effect - the Court went on to state - the sanction provided for in Article 65 of the ACHR assumes the free exercise by the IACHHR of its inherent powers of supervision of the execution of its judgments in the domestic law of the respondent States (paragraphs 90, 113 and 115). Such exercise corresponds to its consistent practice from 1989 until the end of 2003 (paragraphs $103-104$ and 107). In the specific case of Baena-Ricardo et al. (270 workers) v. Panama, the IACHH observed that the respondent State had not previously questioned the Court's powers of supervision, and that in its judgment of 2 February 2001 the Court had already pointed out that it would supervise compliance with it (paragraph 121 ).

19. The Court concluded in this respect that the State's own conduct showed "beyond doubt" that the latter had recognised the competence of the IACHHR to supervise "compliance with its decisions" during "all the monitoring procedure" (paragraph 127). After summarising its conclusions on the matter at issue (paragraphs 128-137), the IACHHR firmly reasserted that it had competence to "continue monitoring full compliance" with the judgment of 2 February 2001 in the cas d'espèce (paragraphs 138-139). It thereby dismissed categorically the challenge of the State concerned, which was never again formulated before the IACHR. The respondent State then proceeded to comply with the judgment in question.

14 For the complete text of the aforementioned opinion, see A.A. Cançado Trindade (2007), Derecho Internacional de los Derechos Humanos - Esencia y Trascendencia (Votos en la Corte Interamericana de Derechos Humanos, 1991-2006), Mexico, Edit. Porrúa/Univ. Iberoamericana, pp. 52-87.

15 See, on this issue: A.A. Cançado Trindade (2005), "International Law for Humankind: Towards a New Jus Gentium - General Course on Public International Law - Part I", in 316 Recueil des Cours de l'Académie de Droit International de la Haye, pp. 177-202, and A.A. Cançado Trindade (2006), A Humanização do Direito Internacional, Belo Horizonte/Brazil, Edit. Del Rey, pp. 3-106 and 394-409.

16 See IACtHR, Juridical Condition and Rights of Undocumented Migrants, Advisory Opinion no. 18 (17 September 2003), Concurring Opinion of Judge A.A. Cançado Trindade, paragraph 81.

17 The IACtHR added that its supervisory function has been accepted by States and by the Inter-American Commission of Human Rights (IAComHR), as well as by the victims or their legal representatives; the IACtHR has thus been able to exercise regularly and consistently its function of supervision of compliance with its own judgments (paragraph 103). 


\section{A SETBACK IN THE PRACTICE OF THE IACTHR: “PARTIAL COMPLIANCE"}

20. Despite the earlier application (in 2000 and 2003) of Article 65 of the ACHR in cases of manifest non-compliance with judgments of the IACtHR (see above), since 2004 the IACtHR has ceased to apply Article 65 of the ACHR (as it should), thus rendering the exercise of the collective guarantee (underlying the ACHR) impossible in the last decade. This, in my perception, ultimately affects the inter-American system of protection as a whole. It demonstrates that there is no linear progress in the operation of an international court (or of any other institution of domestic public law or international law).

21. If the (total or partial) non-compliance by States with the judgments of the IACtHR is not discussed and considered within the competent organs of the OAS - as is the case at present - this generates the mistaken impression or assumption that there is a satisfactory degree of compliance by respondent States with the judgments of the IACtHR. Regrettably, there is not - to the detriment of victims. I thus very much hope that the IACHHR will return to its earlier practice of principle consisting in applying Article 65 of the ACHR in cases of manifest non-compliance with its judgments.

22. The new majority viewpoint prevailing in the IACHHR in recent years (since the end of 2004), consisting in avoiding the application of the sanction provided for in Article 65, has been a "pragmatic" one, in the sense of avoiding "undesirable" clashes with the respondent States and of "encouraging" the latter to move gradually towards compliance with the judgments of the IACtHR. Hence the current practice on the part of the IACtHR of adopting successive resolutions on the supervision of compliance with IACtHR judgments, taking note of this or that measure taken by the States concerned and "closing" the cases concerned partially in respect of the measure(s) taken, in order to avoid discussions on the matter within the OAS.

23. In fact, this gives a false impression of the effectiveness of the "system" of protection, as the cases cannot be definitively "closed" because the degree of partial compliance is very high, just as is the degree of partial non-compliance. And all this is taking place to the detriment of the victims. Cases already decided by the IACHHR are thus kept on the Court's list for an indeterminate period of time, awaiting final "closing" when full compliance has been secured, on the basis of a "pragmatic" approach which seeks to foster "good relations" with the States concerned, thereby avoiding the issue. The IACtHR is an international court, not a conciliation body which tries to "persuade" or "encourage" States to comply fully with its judgments.

\section{FINAL OBSERVATIONS}

24. If there is a sphere in which a very high degree of non-compliance with judgments persists in the inter-American protection system, it is precisely - as already indicated - the investigation of the facts and the punishment of those responsible for grave violations of human rights. In my time as President of the IACHHR, I had due recourse to Article 65 of the ACHR (in the OAS General Assemblies of Windsor/Canada, 2000, and Santiago de Chile, 2003 - the last occasions on which the Court applied that provision), having held a position of principle in that regard rather than a "pragmatic" one. The system of protection exists to safeguard victims, and this consideration ought to have primacy over any others.

25. On the last two occasions (in 2000 and 2003) under my Presidency of the IACtHR when the sanction provided for by Article 65 of the ACHR was applied, the tangible results in terms of the effective protection of human rights under the ACHR were immediate. ${ }^{18}$ In sum, on this jurisdictional point of major importance, the norms of the ACHR exist to be complied with, even if this sometimes leads to problems with a State Party. In ratifying the ACHR, States Parties assumed obligations which are to be complied with (pacta sunt servanda) and constitute obligations of international ordre public.

18 For details, see A.A. Cançado Trindade (2013), El Ejercicio de la Función Judicial Internacional - Memorias de la Corte Interamericana de Derechos Humanos, 3rd. ed., Belo Horizonte/Brazil, Edit. Del Rey, pp. 29-45. 
The ACHR calls for a position of principle in this matter; after all, in order to safeguard the protected rights, it sets forth prohibitions which fall within the sphere of imperative law, international jus cogens.

26. A remarkable illustration of full compliance with Convention obligations is provided by the case of "The Last Temptation of Christ" (Olmedo Bustos et al. v. Chile, judgment of 5 February 2001 ), in which the IACtHR ordered the lifting of film censorship, a measure which involved reforming a constitutional provision. ${ }^{19}$ On 7 April 2003 the respondent State reported to the Court that it had complied fully with the Court's judgment and added that the film at issue was already being shown (since 11 March 2003) in the Cine Arte Alameda in Santiago. In its resolution of 28 November 2003, the IACtHR declared that the proceedings were thereby terminated as Chile had complied fully with the Court's judgment of 5 February 2001.

27. That judgment, delivered under my Presidency of the IACHHR, was not only the first ruling of the Court in a dispute concerning the right to freedom of thought and of expression, but likewise the first case in which full compliance with the judgment required the amendment of a provision of the national Constitution itself. And this was not an isolated episode. Another one of similar historic significance - which also occurred under my Presidency - was that of the case of the Constitutional Court v. Peru, culminating likewise in full compliance by the respondent State with the Court's judgment (Merits and reparations, 31 January 2001), with far-reaching implications for the consideration of the relationship between international and domestic law in the present sphere of compliance with judgments concerning the protection of human rights.

28. In that particular judgment the IAC+HR held that the dismissal of three judges of the Peruvian Constitutional Court amounted to a breach of the ACHR, and ruled that the violation of the right to an effective remedy, and to the judicial guarantees and guarantees of due process of law contained in the ACHR, required restitutio in integrum in respect of the three judges (their effective reinstatement in their posts), given the nature of their functions and the need to shield them from any "external pressures" (paragraph 75). The resolution dismissing the three judges was annulled by the Peruvian Congress even before the aforementioned judgment of 31 January 2001 of the IACHHR.

29. In fact, the National Congress annulled the resolution on 17 September 2000, prior to the holding of the public hearing before the Court on 22 November 2000 in the Constitutional Court case. The three judges were reinstated in their posts with the Peruvian Constitutional Court, which came to be presided by one of them. On the two subsequent occasions - after the reinstatement of the three judges - when I visited the Constitutional Court in Lima (on 12 September 2001 and 18 November 2003), its judges expressed to me their gratitude towards the IACtHR. The episode highlights the relevance of the international court. In a subsequent letter (of 4 December 2003) which, as President of the IACtHR, I wrote to the Constitutional Court, I observed, inter alia, that the IACtHR's unprecedented judgment had repercussions "not only in our region but also on other continents", and marked "the starting point of a remarkable and reassuring convergence between the judiciary at national and international levels which today serves as an example to other countries". ${ }^{20}$

30. This precedent is also reflected in the subsequent convergence which has taken place between the jurisprudence of the IAC+HR and of the Constitutional Court. In the same vein, throughout my long period as Judge of the IACtHR, I defended the view that the corpus juris of protection under the ACHR is directly applicable and that States Parties should ensure full execution of the judgments of the IACtHR. This is not to be confused with the "validation" of judgments, as the IACtHR is an international, and not a "foreign", court; States Parties are bound to comply directly with the IACtHR's judgments without the need for "validation".

19 Namely Article 19 (12) of the Chilean Constitution of 1980.

20 Text of the letter reproduced in: OAS (2004), Informe Anual de la Corte Interamericana de Derechos Humanos - 2003, San José de Costa Rica, IACtHR, Annex LVII, pp. 1459-1460, and compare pp. 1457-1458. 
31. Contrary to what is still widely assumed in several countries, international and national courts are not in conflict, but rather are complementary, engaged in constant interaction for the protection of human rights. ${ }^{21}$ In the Constitutional Court case, the international court intervened effectively in defence of the national court, contributing decisively to the restoration of the rule of law (Etat de droit, Estado de Derecho), besides safeguarding the rights of the victims.

32. In the history of relations between national and international courts, this is a remarkable precedent, one which will continue to be studied for years to come. The two historic episodes I have mentioned here, concerning the closing of the cases of "The Last Temptation of Christ" and the Constitutional Court, pertaining to Chile and Peru respectively, reveal, following due compliance by those States with the IACtHR's judgments, that in this sphere of protection the interaction between international and domestic law takes place in a way that safeguards inherent human rights.

33. In conclusion, the IACHHR, which does not have an organ such as a Committee of Ministers to assist it in the supervision of the execution of its judgments and decisions, has taken that task upon itself. It has done so in the exercise of its inherent powers to exercise such supervision. Much has been achieved, but it has also experienced a setback (in the form of "partial compliance"), as we have seen. Its counterpart the ECtHR has the benefit of the Committee of Ministers, and has recognised the complementarity of its own functions and those of the Committee in this particular sphere. I hope the present review of the experience accumulated by the IACtHR to date may prove useful to my colleagues and friends at the ECtHR currently engaged in the examination of this matter. After all, compliance with the judgments and decisions of contemporary international human rights courts is directly related not only to the rule of law but also, ultimately, to the realisation of justice at national and international level.

21 See A.A. Cançado Trindade (1995), Reflexiones sobre la Interacción entre el Derecho Internacional y el Derecho Interno en la Protección de los Derechos Humanos, Guatemala, Ed. del Procurador de los Derechos Humanos de Guatemala, pp. 3-41; A.A. Cançado Trindade, The Access of Individuals..., op. cit. supra no. (12), chapter V, pp. 76-1 12 (on the interaction between international law and domestic law in human rights protection). 


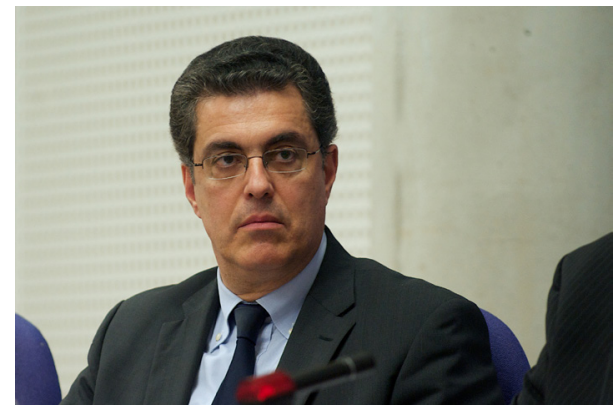

\title{
Linos-Alexandre Sicilianos
}

\author{
Judge of the \\ European Court of Human Rights
}

\section{From the point of view of the Court: its role in the implementation of its judgments, powers and limits}

It is a pleasure and a privilege for me to participate actively in this seminar, organised on the occasion of the opening of the new judicial year, and to give my comments in reply to my old friend Judge Antônio Augusto Cançado Trindade.

The speech we have just heard shows how the concerns of the various systems of human rights protection may overlap. The relationship between the systems set up by the European and Inter-American Human Rights Conventions, far from separation by watertight partitions, has become increasingly symbiotic. The thoughts shared by Judge Cançado Trindade elicit a number of observations concerning the European system.

My first remark concerns the importance of the Committee of Ministers in the functioning of the ECHR system. What the Inter-American Court, under the presidency of Judge Cançado, attempted to put into place, namely a permanent supervisory mechanism, is something that we, for our part, are already privileged to have, on the basis of the European Convention itself.

It should not be denied that the Achilles Heel of the UN system of human rights protection lies in the lack of a strong and permanent mechanism for supervising the implementation of the recommendations of the various committees of experts. Whilst it is true that some of those committees, in particular the Human Rights Committee, the Committee for the Elimination of Racial Discrimination and the Committee against Torture, have set up supervisory mechanisms on their own initiative, it is equally true that it is extremely difficult for the same body of experts (with two or three sessions per year) to examine country reports on a large number of States, to decide on individual communications and, at the same time, to ensure the effective supervision of the measures taken by States in response all the recommendations and opinions thus issued.

In other words, it should be borne in mind that the supervisory mechanism for the execution of judgments of the European Court of Human Rights - with the support of the executions department, assisting the Committee of Ministers - is unique at international level and makes the European system of human rights protection as strong as it is. Admittedly, the functioning of the mechanism in question and the related working methods are constantly evolving and there is still room for improvement. Nevertheless, despite the weaknesses that have been criticised on occasion, the supervisory mechanism established by the ECHR is by far the most efficient internationally.

The activities of the Committee of Ministers have led States, many times, to adopt general measures - legislative, administrative or others - but also individual measures, that is to say, concerning the applicant's own situation. This practice of the Committee of Ministers gives practical effect to the obligation for States to comply fully with the Court's judgments and to take remedial action which, if necessary, will go beyond the payment of just satisfaction.

My second observation based on Judge Cançado Trindade's comments concerns the Court's role in the execution of its own judgments. We have seen that the Inter-American Court of Human 
Rights has been very active on this point and that it has "judiciarised" matters of execution, in particular since 2003-2004.

From around the same time, and with the approval of the Committee of Ministers, the European Court of Human Rights began to follow suit. Over the past decade the Court has thus delivered some 150 judgments referring to Article 46 of the Convention and concerning the execution process.

Categories of judgment - Twenty-three of these judgments emanate from the Grand Chamber, a number are so-called "pilot" or "semi-pilot" judgments - that is to say, judgments concerning structural problems or systemic failings -, but there are also dozens of "ordinary" judgments indicating execution measures which are based expressly on Article 46 of the Convention. That latter category of judgment is important as it shows that the relevant case-law of the Court is not confined to cases which reveal the existence of underlying structural problems, but that it is becoming a common feature.

The content of the measures indicated by the Court differs substantially from one judgment to the next. In the majority of cases, the Court confines itself to identifying the type of measure required for the appropriate execution of its judgments. These are usually general measures, of a legislative, administrative or other nature. Sometimes the Court leaves several options to the respondent State, while providing it with comparative law material to guide its choice. Other judgments, in particular certain pilot or semi-pilot judgments, contain lengthy passages with discussion and analysis of penal policy, detention conditions, etc. Some situations, however, call for individual measures. Where there is only one solution for the execution of its judgment, the Court does not hesitate to indicate a particular individual measure. This is the case, for example, when it comes to the release of an applicant whose detention has been found arbitrary. Lastly, in other cases, the situation may require a combination of both individual and general measures. It may happen, for example, that the adoption of a legislative measure constitutes the prerequisite for the subsequent adoption of an individual measure. This is the case, in particular, where it is necessary to re-open proceedings and such a possibility is not provided for in domestic law.

As regards the legal nature of such measures, there is a sort of continuum. There are "soft" recommendations which leave considerable latitude as to the content of the measures to be taken by the respondent State in the context of execution. There are also recommendations of a compelling nature, or indeed "targeted" recommendations - concerning measures which are relatively precise. In some cases, especially in pilot judgments, the measure indicated by the Court appears in the operative part and is thus particularly mandatory. Such directions may be "soft" where they leave a wide margin to States as to the practical solution. On occasion, however, the directions are more forceful, leaving little or no freedom of choice to the respondent State.

Lastly, as regards the rights concerned, it can be observed that the Court indicates measures of execution relating to a wide range of rights and freedoms enshrined in the Convention, in particular the right to a fair hearing, the right to an effective remedy, the right to liberty and security, the prohibition of ill-treatment or indeed the various aspects of the right to respect for private and family life. Such measures also concern rights that are enshrined in the Protocols, such as property rights or political rights under Article 3 of Protocol No. 1.

My third observation in response to Judge Cançado Trindade's paper concerns the legal basis for the Court's involvement in the execution process. Regarding the Inter-American system, our colleague talked to us about a Convention basis, namely Article 65 of the Inter-American Convention on Human Rights, but also about an opinio juris communis, that is to say a customary basis. In other words, the involvement of the Inter-American Court in the execution of its own judgments has a dual legal basis.

Mutatis mutandis, the same pattern applies to the European system. To justify its approach, the European Court systematically relies on Article 46 of the Convention, which imposes an obligation on States to comply with its judgments. Such obligation concerns not only the payment of just satisfaction; it may also involve the adoption of individual or general measures. Moreover, Article 46, as amended by Protocol No. 14, expressly recognises that the Court has a certain role in the execution process. 
The Committee of Ministers does not seem to have a monopoly in this connection.

Going beyond Article 46 itself, the Court has also relied, especially in the well-known VgT v. Switzerland (no. 2) judgment, on Article 32 of the Convention, which provides for the Court's jurisdiction to decide on its own jurisdiction. The Inter-American Court (like the International Court of Justice and other international courts) has also made use of that principle on various occasions, including in support of its jurisdiction to indicate measures of execution in respect of its own judgments. Moreover, in the Manushaqe Puto v. Albania case, the European Court had occasion to point out that, under Article 19 of the Convention, it had jurisdiction to "ensure" the observance of the engagements undertaken by States in the Convention. In other words - and in accordance with the "implied powers" doctrine - if it finds it necessary to indicate individual or general measures to discharge this task, the Court has the power to do so.

The practice of the Committee of Ministers is equally important. It will be recalled that in its Resolution Res(2004)3, the Committee invited the Court "to identify, in its judgments finding a violation of the Convention, what it consider[ed] to be an underlying systemic problem and the source of this problem, in particular when it [was] likely to give rise to numerous applications, so as to assist states in finding the appropriate solution and the Committee of Ministers in supervising the execution of judgments". That Resolution, adopted at ministerial level on 12 May 2004, reflects the common position of all the Contracting Parties to the Convention. It should therefore be taken into account in the interpretation of the Convention, in accordance with Article 31, paragraph 3 (b), of the Vienna Convention on the Law of Treaties.

This is all the more true as, in its Recommendation $\operatorname{Rec}(2010) 3$ on "effective remedies for excessive length of proceedings", the Committee of Ministers observed that "the case law of the European Court of Human Rights ..., notably its pilot judgments, provide[d] important guidance and instruction to member states in this respect". In other words the Committee of Ministers endorsed, so to speak, the Court's case-law consisting in indicating measures to be taken by States to execute its own judgments. Moreover, and given that respondent States have not as such called into question the Court's jurisdiction in such matters, it would be legitimate to borrow the words of Judge Cançado Trindade and say that an opinio juris communis exists in the European system also.

In conclusion, there is a sound legal basis - a Convention basis and a customary basis for the Court's jurisdiction to indicate to respondent States the measures to be taken to ensure the execution of its judgments.

It is clear, however, that this jurisdiction is not unlimited. My fourth and last observation concerns, precisely, the limits of the Court's power to indicate execution measures. Judge Cançado Trindade was saying, with some regret, that there was no linear progress in the operation of international courts, or indeed, more generally, that of international institutions. That remark resonates like a warning. In other words, it is necessary to be prudent.

Admittedly, from the substantive standpoint, the Court's jurisdiction to indicate execution measures concerns, as we have seen, the substantive Articles of the Convention and the Protocols thereto. The Court is entitled to indicate or even order the necessary general and/or individual measures. It is undeniable, however, that under the Convention the Committee of Ministers has primary responsibility in matters of execution. The Court's jurisdiction in this field remains complementary. This means, first, that it is necessary to maintain the institutional balance under the Convention and, second, that States should be allowed a certain latitude to decide upon and give effect to the most appropriate execution measures.

Generally speaking, the Court's jurisprudential practice of providing the member States with guidelines and instructions in matters of execution has worked quite well thus far. This practice seems effectively to facilitate the task of the Committee of Ministers and the executions department, and also any negotiations with the State concerned. It directs and guides the execution process. However, the Court must avoid being over-prescriptive, so as to leave some discretion to the Committee of Ministers in exercising its own jurisdiction and to the States in choosing the appropriate execution measures, especially as the situation on the ground may evolve after the delivery of the Court's 
judgment. Admittedly, there are cases where the adoption of specific measures (especially individual) is called for, often urgently. However, those cases are exceptional and should, in my view, remain so.

In the same context the question arises whether deadlines should be fixed for the adoption of the requisite measures. If the time-frame is too long, similar cases will be "frozen" in the meantime and the applicants concerned may be unduly affected. If the time-frame is too short, it may prove unrealistic and create difficulties for the Committee of Ministers, for the States and, ultimately, for the Court itself. A similar question arises mutatis mutandis with regard to a possible request for the re-opening of proceedings at domestic level. This could be indicated in criminal (or administrative matters). In civil matters, however, such re-opening could, on occasion, call into question the rights of bona fide third parties.

More generally, what is the Court's role in the event of a failure to execute a judgment? If a case is pending before the Committee of Ministers, should the Court not refrain provisionally from dealing with a new application from the same applicant or applicants and concerning the same factual context? What new policies or practices could be developed to enhance the Court's role in the execution process? These are questions which remain open.

In conclusion, the traditional approach whereby the Court always rendered purely declaratory judgments and the Committee of Ministers had exclusive jurisdiction to supervise the execution of those judgments no longer corresponds to the current situation. The Court has gradually come to play a key role in matters of execution. The pilot judgment procedure is the most striking example in this connection, but it is not the only one. The Court has developed its case-law beyond that procedure by indicating, or even ordering, the general and/or individual measures to be taken by States and affecting a broad range of substantive rights. The Court's jurisdiction in such matters has a sound legal basis, deriving both from the Convention and from custom. It remains, however, complementary in relation to that of the Committee of Ministers. While the Court's case-law will have to be developed and fine-tuned with a view to the better execution of its judgments, it is also essential to preserve the institutional balances provided for in the Convention and to leave States, in principle, a certain latitude in order to decide on and give effect to the most appropriate measures of execution. 


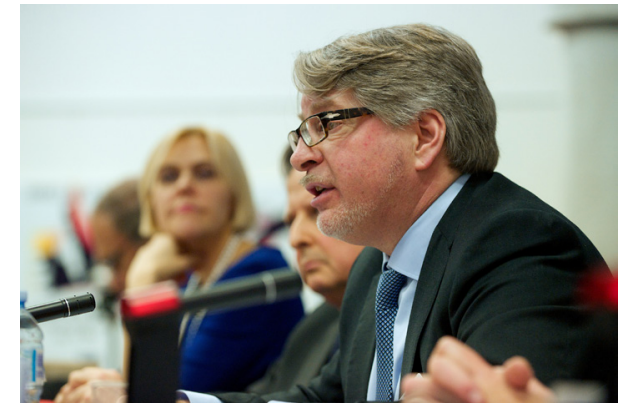

Alec Stone Sweet

\author{
Professor, \\ Yale Law School, United States of America
}

The Role of National Courts in the Implementation of the Court's Judgments

\title{
INTRODUCTION
}

The second topic of the Seminar - the role of national courts in the implementation of the Court's judgments - is both vast and complex. It also raises many important questions for which we have no definitive answers, not least, because relatively systematic, comparative research on implementation did not exist until recently.

We do know' that there is wide variance - both across and within national legal orders - in how the Court's rulings are implemented. Variance across national systems is partly determined by how the Convention has been incorporated into national law, and then by how national judges use the Convention in light of their own constitutional arrangements. To make matters more complicated, we also find a great deal of variation inside national legal orders. In a majority of European states, no single "model" of implementation exists. In systems with multiple high courts, for example, national judges do not always agree among themselves on a common approach to enforcing the Convention. In all states, some judges are more receptive than others to the Court's jurisprudence; and resistance to the Court's influence is more pronounced in some areas of the law, compared to other domains. At the same time, incorporation and Protocol No. 11 combined to create a Community of courts, a pan-European, rights-based Commons of which many of you are all important members. In this common judicial space, no court at any level can fulfill its rights-protecting missions without the support and cooperation of other courts. ${ }^{2}$

In my contribution to the Seminar, I will focus in more detail on three of the points just made: (1) the incorporation of the Convention into national law; (2) the impact of incorporation and Protocol No. 11 on rights protection through national courts; and (3) the role of inter-judicial cooperation in building a Community of courts.

\section{INCORPORATION}

The European system of rights protection has been transformed by the combined effects of (1) the entry of force of Protocol No. 11 (1998), which confers upon individuals a right to petition the European Court after exhausting national remedies, and (2) the incorporation of the Convention into national law. These structural changes produced a new and unique legal system which, for all of its problems, is the most effective human rights regime the world has known. Managing this multi-level system is the collective responsibility of the European Court, the Committee of Ministers, national governments and parliaments, and national judges. I will begin by focusing on some structural features of this system, as they pertain to national courts.

1 See Helen Keller and Alec Stone Sweet (2008), A Europe of Rights: The Impact of the ECHR on National Legal Systems (Oxford: Oxford University Press); Leonard Hammer and Frank Emmert, The European Convention on the Human Rights and Fundamental Freedoms in Central and Eastern Europe (The Hague: Eleven, 2011).

2 A. Stone Sweet (2012), "A Cosmopolitan Legal Order," Journal of Global Constitutionalism 1, 53 - 90. 
The first and most basic point is that the Convention is no longer mainly a species of international law: it is national law that is directly enforceable by national judges. Today, every Contracting Party has domesticated the Convention. Incorporation proceeded by different routes: through express constitutional provision (many states in Central and Eastern Europe and the Balkans); through judicial interpretation, especially of constitutional provisions governing the status of treaty law (most States in Western Europe); and through special human rights statutes (the UK, Ireland, and Scandinavian states). With incorporation, the Convention becomes binding not only on states, as a matter of international law, but on every state official who exercises public authority, as a matter of domestic law. Today, virtually all national courts in the system are capable of enforcing the Convention: individuals can plead it at national bar against virtually any act of public authority; judges are under a duty to identify parliamentary statutes that conflict with rights, and to interpret statutes in light of the Convention, in order to avoid conflicts whenever possible; and judges are expected to refuse to enforce statutes found to be incompatible with the ECHR, although there are notable exceptions (the UK and Ireland).

The vast majority of cases involving Convention rights before national courts do not require the judicial review of statutes. I have, nonetheless, emphasized this form of review to highlight the profound transformation in the nature and scope of judicial authority brought about by the incorporation of the ECHR. National courts are today positioned to enforce the Convention but, to arrive at this point, most systems had to overcome a deeply-rooted constitutional orthodoxy: the prohibition of judicial review of statute. When the ECHR was signed, only Ireland, among original signatories, had any meaningful experience with judicial review, or possessed an enforceable charter or rights. As rightsbased, constitutional democracy spread across Europe, most systems established constitutional courts in order to protect fundamental rights, while maintaining the prohibition of judicial review of statute. By conferring upon the Convention at least a de facto rank above that of parliamentary legislation, the prohibition was overcome. Similarly, in so-called dualist states, in which treaty law enters into national law with the same rank as statute, the lex posterior derogat legi priori rule had to be relaxed, in order for the Convention to be enforceable in a conflict with legislation.

In these and other ways, incorporation has been directly implicated in constitutional change. The Convention now functions as a "surrogate" charter of rights in states that do not possess their own judicially-enforceable charters (including France, the Netherlands, Switzerland, and the UK). Finland, Norway, and Sweden enacted new Bills of Rights, closely modeled on the Convention, in order to fill gaps in their own constitutional law. In those States that possess, at least on paper, relatively complete systems of constitutional justice, incorporation provides supplementary protection. This is the situation in Germany, Greece, Ireland, Italy, Portugal, Spain, Turkey, and in the post-Communist States.

With incorporation, the Convention and national constitutional law are not easily dissociated. In Spain, the Constitutional Tribunal enforces the Convention in synergy with constitutional rights. The Tribunal will strike down statutes that violate the Convention as per se unconstitutional; it interprets Spanish constitutional rights in light of the ECHR, wherever possible; and it has ordered the courts to implement the Strasbourg Court's jurisprudence as a matter of constitutional obligation, including precedent generated in cases not involving Spain. If the judiciary ignores the Tribunal's jurisprudence, individuals can appeal directly to the Tribunal for redress. The German Federal Constitutional Court, despite a surface commitment to constitutional dualism, has recently taken a similar position, relaxing the lex posterior rule. In many post-Communist States, as well, constitutional judges invoke the Strasbourg Court's jurisprudence as authority, in order to enhance the status of constitutional rights - and hence their own positions - in the national legal order.

Strikingly, some States give the Convention constitutional rank (e.g., Albania, Austria, Slovenia); and, in the Netherlands, the ECHR enjoys supra-constitutional status, which is also the position of the Belgian Supreme Court, but not the Constitutional Court.

Through incorporation, every national legal system has adapted to the post-Protocol No. 11 regime in ways that have fundamentally altered its constitutional structures and practices, and in ways meant to facilitate implementation of the rulings of the European Court. 


\section{PLURALISM WITHIN NATIONAL LEGAL ORDERS}

Protocol No. 11 and incorporation have combined to create a multi-level, pluralistic system of rights-protection in Europe. ${ }^{3}$ I do not use the word "pluralistic" just to be fashionably academic. Pluralism denotes a legal fact, a structural property of a legal system. ${ }^{4}$ With respect to national systems of rights protection, it describes two types of situations (legal facts). The first type is "source pluralism," wherein two or more autonomous sources of judicially-enforceable fundamental rights co-exist. In most national legal systems, constitutional rights and Convention rights overlap and, in member states of the European Union, the rights found in EU law are also available. Individuals may have a choice of which source to plead, and judges often have choices of which right to enforce. Such choices are directly implicated in the question of how the European Court's judgments are implemented.

The second form of pluralism is "jurisdictional," wherein at least two high courts claim autonomous authority to interpret and apply fundamental rights, and no one court can consistently impose its interpretation of rights on the other. ${ }^{5}$ Consider the Belgian case just mentioned, where two high courts do not agree on the status of the Convention in the hierarchy of norms. Some significant measure of jurisdictional pluralism is found in all states in which judicial power is distributed among specialized courts - the majority of states in the Council of Europe today - but where the right of individual petition to a Constitutional Court is absent. Where individuals can challenge a judicial decision before the constitutional court, or where there is a single final court of appeal, the development of significant jurisdictional pluralism can be blocked.

In many states, the two forms of pluralism combine. Consider the example of France, which for two centuries embraced the prohibition of judicial review of statutes, but which is now a robust example of rights pluralism. From the point of view of the individual rights claimant, the Supreme Civil Court (Cour de Cassation) and the Conseil d'état (the supreme administrative court) function as the "real" constitutional courts; and litigants and judges treat the Convention as the "real," that is, de facto charter of rights. The reason: individuals have no direct access to the Constitutional Council, despite recent constitutional changes; and it is the European Court, not the Constitutional Council, that most directly supervises the rights-protecting activities of the civil and administrative courts. Today, three autonomous high courts in France protect fundamental rights on an ongoing basis.

Incorporation expanded judicial power, with respect to legislative and executive power, throughout Europe. In most states, it also created source pluralism, while enhancing jurisdictional pluralism in those systems in which judicial authority was already divided among separate high courts. These facts are enormously important to our topic. In a pluralist context, judicial outcomes are not generated mechanically, through top-down, command and control mechanisms. Judges have hard choices to make from a complex menu of options. Implementing the Court's important rulings will always involve multiple considerations, including the probable impact of implementation on existing constitutional doctrine and precedent, on other lines of substantive case law, and on relationships with executives, legislators, and other judges. In situations of jurisdictional pluralism, rights protection proceeds through delicate inter-judicial dialogues, both cooperative and conflictual. The result of these dialogues can be decisively influenced by rulings of the European Court: the national court that is on the side taken by the Strasbourg Court will usually prevail.

Generally, incentive structures push national judges toward implementation of the Court's judgments. Simplifying a complex topic, and at the risk of sounding like a political scientist, there are three basic logics at work. The first is an "avoidance of punishment" rationale: enforcing Convention

A. Stone Sweet, "A Cosmopolitan Legal Order," op cit.

A. Stone Sweet (2013), "The Structure of Constitutional Pluralism," International Journal of Constitutional Law, 1 1: 491-500.

L. Garlicki (2007), "Constitutional Courts versus Supreme Courts," International Journal of Constitutional Law 5, 44-68; Wojciech Sadurski, Rights Before Courts: A Study of Constitutional Courts in Post-Communist States of Central and Eastern Europe (Springer 2005): 20-25. 
rights will make the state - in practice, judges - less vulnerable to censure in Strasbourg. This logic is especially pronounced in systems that otherwise prohibit the judicial review of statute, or do not have a national charter of rights. A second dynamic is embedded in domestic law and politics. Individuals, lawyers, and groups may invoke the Convention before national judges as part of a strategy to change national law and policy; and national judges may seek to entrench Convention rights in order to enhance their own authority with respect to legislators and executives, and other national courts. This is a "judicial empowerment" rationale: to the extent that judges respond to demands to protect rights effectively, they will empower themselves, whether or not they intend to do so. Third, as the European Court has consolidated its role as a primary, authoritative source of rights doctrine and standards, the interest national judges have in constructively engaging the Court in dialogue increases. Even for national judges who are relatively jealous of their own autonomy, engaging the Convention and its Court is more likely to inject national values into decision-making in Strasbourg than the more costly alternative: defection and open conflict.

I do believe that it is legitimate for a national court to refuse to implement certain types of rulings of the European Court. When the Strasbourg Court, for instance, balances two rights that are in tension differently than have supreme or constitutional judges beforehand, the Court does not apply higher standards of protection for one right, without lowering it for another. In such cases, what is important is that both courts demonstrate that they have resolved these hard cases in good faith, fully aware that the other court may decide differently.

In any event, in a pluralist system of rights protection, friction among national officials, and between national courts and the European Court, can never be eliminated. How this friction should be managed is, of course, the crucial question for everyone present today.

\section{A COMMUNITY OF COURTS}

I have claimed that Protocol No. 11 and the incorporation of the Convention combined to give birth to a new legal system, one in which a Community of courts shares the formal responsibility to enforce the Convention. The system is pluralistic: neither a national court nor the Strasbourg Court has formal powers to impose its interpretation of rights on the other. Instead, just as in those national legal orders characterized by jurisdictional pluralism, rights protection proceeds through inter-court dialogues. The necessary condition for dialogue is that every high court recognizes the authority and legitimacy of every other high court. Such recognition creates a Community of courts. A necessary condition for successful dialogue within this Community is that each court, including the European Court, recognizes that every other court may have good reasons to differ on how rights are to be interpreted and applied in the context of any specific dispute.

These points made, the Strasbourg Court holds the status of "first among equals" in this Community. Indeed, it has emerged as a kind of transnational constitutional court, and for well-known reasons. The Court performs many of the same functions that powerful national constitutional courts do, using similar techniques, with broadly similar effects. It confronts cases that would be classified, in the context of domestic law, as inherently "constitutional." It holds that its important precedents bind all judges in the system. It adjudicates qualified rights just as constitutional courts do, through proportionality-based balancing. It routinely indicates how a state might or must reform its law in order to avoid future violations. And its most important rulings place national executives, legislators, and courts "in the shadow" of future litigation, provoking the kind of dynamic adaptation - rightsoriented jurisgenerativity - that one finds in the most effective national systems of constitutional justice. These developments are justified to the extent that they enhance the effectiveness of rights protection, which is, after all, the central priority of the system. Even if we reject the "constitutional" label, the Community of Courts needs a manager, and the Strasbourg Court is the only court positioned to perform this role.

As "first among equals," the European Court is under a special duty to facilitate dialogue within the Community. Most important, it must fully acknowledge the complexity of the national judge's task in enforcing Convention rights, while - simultaneously-considering the transnational dimensions 
of specific cases. How well the Court does so will bear on implementation. In its rulings, the Court takes great pains to trace the process through which individuals have exhausted remedies, and it responds to all of the arguments submitted by the defendant state. Some state officials may disagree with a finding of violation, but it is not plausible to argue that the Court fails to take domestic law and context, or the state's views, seriously. More controversially, in the context of the qualified rights (Articles 8-12 ECHR), the Court will typically raise standards of protection in a given domain when a sufficient number of States have withdrawn public interest justifications for restricting the right. The margin of appreciation thus shrinks as transnational consensus on higher standards of rights protection emerges. ${ }^{6}$ From the point of view of national judges in states that have fallen behind, destabilization is the result. Nonetheless, in considering national law and practice comparatively, in light of transnational values and practice, the Court forcefully proclaims that no national court is alone when it adjudicates rights. Rights protection in a Community of courts is a collective process.

To conclude, I will emphasize a point that deserves to be better appreciated in difficult times. In the Convention system, in which national judges have an integral role, it is individuals - not states - who are the major stakeholders. Under traditional conceptions of international law, states were the dominant actors, the entities that mattered. In practice, the interests of the state typically reduced to the interests of the executive. Today, in the system produced by Protocol No. 11 and incorporation, "states" are mostly legal fictions. Judges do not exercise authority over "states." Judges review how specific national officials, operating in diverse contexts, take decisions that affect the fundamental rights of individuals that come under their jurisdiction. It is their duty to do so because it has been decided that, in Europe, no act of public authority is legally authorized or legitimate if it violates fundamental rights.

6 A. Stone Sweet and T. Brunell (2013), "Trustee Courts and the Judicialization of International Regimes: The Politics of Majoritarian Activism in the ECHR, the EU, and the WTO," Journal of Law and Courts, 1: 61-88. 


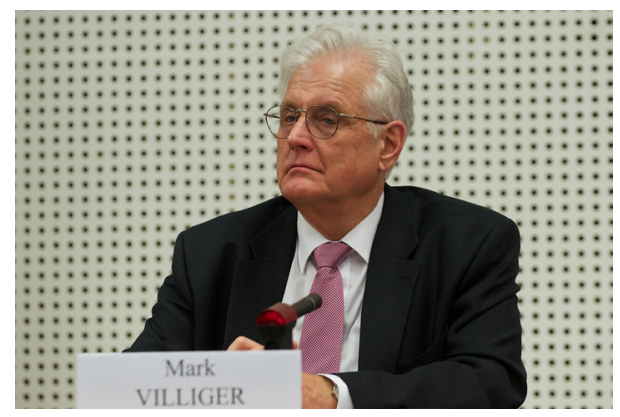

\title{
Mark Villiger
}

\author{
Section President \\ of the European Court of Human Rights
}

\section{From the point of view of national judiciaries: The role of national courts in the implementation of the Court's judgments}

The presentation by Professor Stone Sweet has shown us the intricacies of the national legal orders in their reactions to the requirements of the Convention as interpreted and applied by the Strasbourg Court in its case-law.

I shall deal with this subject - the role of national courts in the implementation of the Court's judgments - from the perspective of a judge of the Court. ' We are talking in particular about the superior and highest national courts.

This is very much an exercise in empathy: How do we in the Court see the national courts in their endeavours to implement our judgments? What do they expect from us, and we from them, what are the difficulties we consider they will have, and what should our relations be with the national courts?

In dealing with the subject, I shall briefly discuss seven points and make seven propositions. Of course I am only expressing my own personal views.

As a first point, the implementation of the Court's judgments falls in principle to the respondent Government, often its Foreign Ministry or Ministry of Justice - which will then decide on any measures to be taken, for example amending legislation, refurbishing prisons and so on. Governments play a primary role here. Governments then report back to the Committee of Ministers of the Council of Europe on the measures which have been undertaken. National courts only exceptionally directly implement the judgment as such, for instance by ordering the reopening of the proceedings - which, of course, presupposes a domestic law enabling such a procedure.

My first proposition is, therefore, that as a rule national courts contribute indirectly to the implementation of judgments. They assure that in subsequent domestic cases their decisions comply with the Strasbourg case-law.

Here, I hasten to add my second point and proposition: we in the Court should constantly be aware that the highest national courts, even indirectly, nevertheless play a central and crucial role in the implementation of the Court's judgments on account of their hierarchical position in the domestic judiciary. It follows that the Strasbourg Court and the domestic courts should deal with each other against a backdrop of high mutual respect.

This brings me to my third point. The Court has analysed at length the reasons for its backlog of pending applications - and is of course constantly searching within its own four walls for the means to become even more efficient. However, for some time now, the Court has been confronted with various series of repetitive applications against a number of countries leading to a staggering volume of cases. And it has been clear for some time that the explanation for this lies in the fact that 
some national courts may encounter difficulties in following the Court's judgments. The judgments which they issue may, for whatever reason, not always sufficiently consider the Court's interpretation of the Convention and hence lead to many further applications to Strasbourg.

Therefore, a third proposition is that if national courts were to consistently implement the Convention in its interpretation and application by the Court, the case-load before the Strasbourg Court would be considerably reduced - it would dramatically lessen.

My fourth point is that one difficulty which domestic courts, particularly Supreme and Constitutional Courts, face when attempting to comply with the Court's judgments are the requirements of their own domestic order. To mention two examples, the Court's judgments may be difficult to reconcile with the national Constitution, not least its overarching position in the domestic hierarchy of laws; or the Court's judgments may go against the results of popular referenda in which the populace has freely and democratically expressed itself on a law or a constitutional provision. Here subsidiarity comes into play in two respects. ${ }^{2}$ On the one hand, subsidiarity discourages the Court from indicating to the national courts a way out of this quandary. On the other hand, subsidiarity requires the Court not to close its eyes to such domestic problems - and to attempt to analyse and understand how the concrete human rights issue before it arose, so as to issue an informed, convincing and authoritative judgment which is aware of the domestic backdrop to the case. The extent to which the margin of appreciation should play a role in such a situation - it has even been suggested giving it a reinforced role - goes beyond the confines of this presentation.

A fourth proposition is, therefore, that the Court is not as such in a position to resolve domestic legal debate and controversy. The Court's sole duty (and it is already big enough!) is to interpret and apply the Convention. On the other hand, the Court can only issue informed and authoritative judgments if it is aware of the predicaments of domestic courts under national law as regards the interpretation and application of the Convention.

Fifth, as we have heard in this seminar today, the Court has for some years now in its judgments made recommendations to the domestic courts under Article 46 of the Convention as to how they can best implement its judgments. ${ }^{3}$ Typically, since Gencel v. Turkey, the Court has, in cases concerning the fairness of proceedings under Article 6 of the Convention, suggested the reopening of the case in the domestic courts. ${ }^{4}$ It has also gone further and urged, for example in Mandić and Jović v. Slovenia, that the respondent Government take steps to reduce the number of prisoners in a domestic prison. ${ }^{5}$ It has even seemingly instructed States, for instance in Assanidze v. Georgia, to release an applicant from prison. ${ }^{6}$

The question arises whether the Court is intruding upon the sovereignty of member States and/or extending the competencies which it has received under the Convention. Indubitably, it would be out of order for the Court to impinge on the independence of a domestic court.

Nevertheless, it is my view that the question does as such arise whether the Court is transgressing its limits, since in fact it is making recommendations - at times in soft terms, at times less softly. Still, even in Assanidze, where the applicant had to be released from prison - and this is often cited as a judgment employing direct terms - the Court stated that "by its very nature, the violation found in the

2 See, on this subject, M. E. Villiger (2007), "The Principle of Subsidiarity in the European Convention on Human Rights", in M. G. Cohen (ed.), Promoting Justice, Human Rights and Conflict Resolution through International Law. Liber Amicorum Lucius Caflisch, p. 623.

3 See, on this subject, among the scant but growing literature, including within this volume, inter alia, J. Jahn (2014), "Ruling (In)directly through Individual Measures? Effect and Legitimacy of the ECtHR's New Remedial Power", Zeitschrift für ausländisches öffentliches Recht und Völkerrecht 74, $1 \mathrm{ff} ; \mathrm{G}$. Nicolaou (2011), "The New Perspective of the European Court of Human Rights on the Effectiveness of its Judgments", in Ch. Hohmann-Dennhardt et al (eds.), Festschrift für Renate Jaeger. Grundrechte und Solidarität: Durchsetzung und Verfahren, p. 163.

4 Gencel v. Turkey, no. 53431/99, § 27, 23, ECHR, October 2003 ("IIJorsque la Cour conclut que la condamnation d'un requérant a été prononcée par un tribunal qui n'était pas indépendant et impartial au sens de l'article $6 \S 1$, elle estime qu'en principe le redressement le plus approprié serait de faire rejuger le requérant en temps utile par un tribunal indépendant et impartial").

5 Mandić and Jović v. Slovenia, nos. 5774/10 and 5985/10, §§ 124 et seq., 20 October 2011, ECHR 2011.

6 Assanidze v. Georgia, no. 71503/01, §§ 201 et seq., 8 April 2004, ECHR 2004-II. 
instant case does not leave any real choice as to the measures required to remedy it". ${ }^{7}$ So the Court is still giving the respondent Government some leeway and the possibility of claiming that there may well have been another real choice available (which in that case, seemingly, was not so).

$C^{\prime}$ est le ton qui fait la musique! It appears difficult to criticise the Court for giving guidance. However, the Court must bear in mind any sensitivities on the part of the national authorities in this respect. Thus, in Konstantin Markin v. Russia the Chamber "recommended" that the respondent Government take measures with a view to amending domestic legislation. ${ }^{8}$ Before the Grand Chamber in the same case, the respondent Government reacted to this recommendation and reproached the Court for the fact that it had been "ordered" by the Chamber to undertake such amendment."

A fifth proposition is, therefore, that the Court is competent to issue recommendations under Article 46, though not instructions as such. When issuing its advice the Court should do so in carefully phrased language, bearing in mind the limits of its jurisdiction.

Sixth, do national courts wish at all to be given such recommendations by the Court? In my view, as long as the Court remains within the confines of the Convention, national courts will surely appreciate the Court's recommendations on how to implement its judgments! After all, the Court has just analysed the case in its judgment and is in the very best position to give such guidance. It will do so solely out of a concern for present and future applicants, not least to prevent further applications on the same subject-matter. That these recommendations actually do appear valuable to national courts, particularly the highest ones, would seem confirmed by the fact that very little criticism has been heard from the national courts in this respect. On the contrary, if anything, the Court has been exhorted in informal conversations that, if it does find a violation, it should inform the national courts more frequently as to how it considers that the violation could be remedied.

A sixth proposition would therefore be that it is in the interest of the national courts themselves that the Strasbourg Court makes recommendations in its judgments - and that the Court should, if anything, extend, rather than reduce, this practice.

Finally, the seventh point. There remain various further theoretical and practical objections. For instance, why should a domestic court - independent and impartial as it is - take advice from any other institution? How should the Government, at which the judgment is directed, deal with such recommendations towards its own domestic courts? And how can the national courts express themselves if they disagree with the Strasbourg Court and find that the recommendation made was actually not pertinent or even wrong.

In the long run, these and many other questions can in my view only be resolved by means of the dialogue between judges - which itself was a topic some years ago at this Seminar for the Opening of the Judicial Year. ${ }^{10}$ This dialogue consists in the domestic courts and the Strasbourg Court communicating with each other - on the one hand, through their judgments which they regularly exchange (a sort of ping-pong effect), and on the other, through informal discussions which constantly take place with the highest national courts either here in Strasbourg or in their home countries. Such ongoing dialogue remains essential, indeed cardinal.

So I would round off my presentation with a seventh proposition, namely that the Strasbourg Court and the domestic courts should continue to engage in regular dialogue with each other in order to understand their respective positions, difficulties and sensitivities as regards the interpretation and application of the Convention and the implementation of the Court's judgments in the national legal orders. 


\section{SOLEMN HEARING}

\section{OF THE EUROPEAN COURT OF}

\section{HUMAN RIGHTS}

ON THE OCCASION OF THE OPENING

OF THE JUDICIAL YEAR 


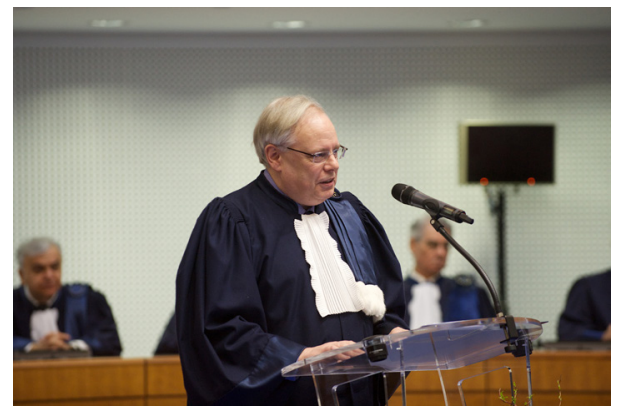

\title{
Dean Spielmann
}

\author{
President \\ of the European Court of Human Rights
}

Presidents of Constitutional Courts and Supreme Courts, Chairman of the Ministers' Deputies, President of the Parliamentary Assembly, my compatriot and friend Anne Brasseur - with my congratulations for your election, Secretary General of the Council of Europe, Excellencies, Ladies and Gentlemen,

I would first like to thank you, personally and on behalf of all my colleagues, for honouring us with your presence at this solemn hearing for the opening of the judicial year of the European Court of Human Rights. By responding to our invitation you have, once again, confirmed the strength of the connections between us. As there are still a few hours left before we reach the end of January, I will keep to the tradition and wish you an excellent and happy new year 2014.

Again following our tradition at these solemn hearings, I would now like to look back at some of the events which have marked the past year in the life of the Court.

As you will no doubt recall, last year I announced in this very place the fact that in 2012, for the first time in its history, the Court had managed to stem the rising backlog of new applications.

That positive trend, which I commended by saying that the Court was no longer a victim of its own success, was confirmed in 2013 . The number of applications disposed of by a judgment amounted to 3,659, up from 1,678 the previous year. In total, the Court ruled in over 93,000 cases, representing a $6 \%$ increase in relation to 2012 . At the end of 2012 , there were 128,000 pending applications. That figure dropped to 99,900 at the end of 2013 , representing a $22 \%$ decrease and, above all, pushing the backlog below the symbolic threshold of 100,000 applications.

But there are other reasons why, in my opinion, the year 2013 deserves to be celebrated: developments which should bring us even closer together in the future, and I am thinking here in particular about those of you who are representing a supreme or constitutional court. For in the past year the European Convention on Human Rights, an instrument that is now sixty years old, has been complemented by two new protocols.

It is the second one, Protocol No. 16, that I wish to emphasise, as its aim is to bring about a new dialogue between the highest domestic courts and our Court. I thus like to refer to it as the "Protocol of dialogue".

This instrument, which will enter into force after ten ratifications, will enable your highest courts, should they so wish, to refer requests to the Court for advisory opinions on questions of principle concerning the interpretation or application of the rights and freedoms defined by the Convention. Such requests will be made in the context of cases that are pending before the domestic court. Our Court's advisory opinion will provide reasoning and will not be binding. As an additional means of judicial dialogue between the Court and national courts, it will have the effect of enlightening the highest domestic courts but they will not be compelled to follow it. I am convinced that, when they do choose to rule in accordance with our opinion, their authority will be strengthened for the greater benefit of all. Cases may thus be resolved at national level rather than being brought before our Court, even thought that option will remain open to the parties after the final domestic decision. By 
providing our Court and national supreme courts with a partnership-based tool, Protocol No. 16 will fulfil what Professors Ost and van de Kerchove referred to as the transition "from pyramid to network".

The mechanism will serve to institutionalise an already longstanding dialogue between our courts that is manifested not only on the occasion of this annual event, but also through the visits paid to Strasbourg by delegations from supreme courts or my own official visits to member States. It is a dialogue which is also, and most importantly, maintained through the interaction between our respective case-law.

For some years now the law of the Convention has indeed been a source of inspiration for both the courts and the legislatures of the member States. We have thus witnessed - and this is what subsidiarity means - a "tendency to bring the protection of fundamental rights back to the States", to use the expression of the Vice-President of the French Conseil d'État, Jean-Marc Sauvé, in a speech that he gave here at a previous solemn hearing. Such a tendency is most welcome, in my view, provided that it does not conflict with our case-law, by diminishing its importance. Our caselaw inspires both judges and law-makers. It permeates and guides the law of the member States and thus gives rise to an almost permanent dialogue between Strasbourg and the domestic courts, which are continuously and quite naturally asking themselves, in a given dispute, what the European Court would decide if it were to hear the case. Above all - and this a recent, but most noteworthy, phenomenon - domestic courts do not hesitate to go beyond our case-law and the standards set by the Court. As to the legislatures, they follow suit when it comes to amending national legislation.

This is neither the place nor the time to enumerate all the supreme court decisions based on our case-law. It would not be an easy task as those decisions are so numerous, and occur on a daily basis, in our 47 member States. I would refer to just one example of a national decision which is part of a broader picture. It is the non-judicial decision delivered on 27 June 2013 by the plenary bench of the Supreme Court of the Russian Federation, reminding all Russian courts of their obligation to follow the Strasbourg case-law and observing that, to ensure the effective protection of human rights and freedoms, they had to take into account the judgments of our Court, including those against other States parties to the Convention. That decision thus enshrines the principle of the erga omnes value of our case-law.

As to Russian legislation on rights and freedoms, that decision emphasises that laws have to be implemented in the light of our Court's judgments. I believe that we can all appreciate the significance of that decision, especially as it comes from a country which remains the source of the highest number of applications.

By giving prominence to our own interpretation of the rights guaranteed by the Convention, the Supreme Court of the Russian Federation has proclaimed the importance of Strasbourg as guarantor of a common area of protection of rights and freedoms. We can be proud of this, especially as we know how far we have come. But that decision also imposes a heavy responsibility on our Court and gives rise to certain duties, in the same way that it creates duties for the national courts. Our system, which has become a source of inspiration for domestic courts, must strive to seek a consensus, while respecting cultural identities and traditions, without ever turning its back on the principles which have guided it from the outset. This is the dilemma constantly facing our Court.

To maintain the quality and authority of our case-law is for us a permanent goal, for that is what has made our human rights protection system successful. In 2013, despite the considerable efforts made to increase our productivity and the positive results obtained, we have indeed endeavoured to maintain the quality of our judgments.

It is never an easy task to select, from all the decisions over the past year, those that warrant particular consideration on the occasion of this solemn hearing. I have chosen just two.

The first is the case of $X$. and Others v. Austria, delivered on 19 February 2013, concerning the sensitive question of the legal status of families with parents of the same sex. The applicants were two women in a stable relationship and the son of one of those women. They complained about discriminatory treatment, on account of the fact that under Austrian law same-sex couples were 
excluded from second-parent adoption whereas it was open to unmarried heterosexual couples. Our Court found against Austria for discrimination in the right to respect for family life. In our view the discrimination stemmed from the fact that the courts had no opportunity to examine in any meaningful manner whether the requested adoption was in the child's interest, given that such adoption was legally impossible under the Austrian Civil Code. It was not the actual prohibition of adoption that led to our finding of a violation, but the discriminatory conditions of its availability to unmarried different-sex couples. It was thus through the prism of the prohibition of discrimination that our Court intervened. For us it was clear - and I quote - that "same-sex couples could in principle be as suitable or unsuitable for adoption, including second-parent adoption, as different-sex couples" and, even though there was no right to adopt a child, such discrimination was incompatible with the Convention.

Going beyond the actual significance of the judgment in terms of the Court's position on this sensitive issue, attention should also be drawn to its execution by the Austrian authorities for the good example that they have set. On the very day our judgment was delivered, the Austrian Ministry of Justice announced that a bill would be tabled before the summer in order to bring Austrian legislation into conformity with our case-law, adding that the necessary legislative amendments would be adopted before the end of the parliamentary term. Thus, on 1 August 2013, a law entered into force amending the provisions of the Civil Code to make second-parent adoption available to same-sex couples.

The second case I wish to mention was equally delicate, albeit in a very different domain: the Del Rio Prada judgment, delivered on 21 October 2013. That case concerned the postponement of the date of final release of a person convicted of terrorism. This postponement was the result of new case-law of the Spanish Supreme Court - referred to as the "Parot doctrine" - which had been given effect after the applicant's conviction.

The applicant had been given numerous prison sentences for various offences linked to terrorist attacks. The sentences totalled over 3,000 years but, under the Criminal Code in force at the time when the offences were committed, the applicant was to serve a maximum term of thirty years. She had also been granted almost nine years' remission for work done in prison and was due to be released in 2008 .

In the meantime, the Spanish Supreme Court had departed from its previous case-law and had extended her imprisonment until 2017.

Before our Court, the applicant complained first that what she considered to be the retroactive application of a departure from case-law by the Supreme Court had extended her detention by almost nine years, in violation of the "no punishment without law" principle in Article 7 of the Convention. Secondly, under Article $5 \S 1$, she alleged that she had been kept in detention in breach of the requirement of "lawfulness" and without "a procedure prescribed by law".

Our Court took the view that the application of the "Parot doctrine" to the applicant's situation had deprived of any useful effect the remissions of sentence to which she was meant to be entitled. It had not been foreseeable, at the time of her conviction, that the Supreme Court would depart from its case-law in February 2006. The application of the new case-law to the applicant's case had postponed her release by about nine years. She had thus had to serve a sentence of a longer term than that which should have been imposed under the Spanish legal system as it stood at the time of her conviction, taking into account the remissions granted to her in accordance with the law. As regards both the legality of the sentence and the lawfulness of the detention, the Court thus found a violation of the Convention. It also held that it was incumbent on the Spanish Government to ensure that the applicant was released at the earliest possible date.

On the very day that the judgment was delivered, the Spanish Government drew attention to the binding nature of the Court's judgments. The next day, the Spanish judicial authorities decided to release the applicant, followed by other prisoners in the same situation. It is no doubt rare for one of our judgments to be executed so quickly.

Those two cases, although very different, contain similarities which have led me to choose them from among all those of 2013 that would also have been worthy of mention this evening. 
In legal terms, the two cases raise new, and even quite novel, questions. They illustrate the huge variety of subjects that our Court is called upon to examine. They have also been followed with particular attention in the countries concerned, both by the national authorities and by the media. Our Court - and this brings me back to the point I made just now - was aware of the responsibility that it had to assume. But that responsibility goes hand in hand with its duty to ensure compliance with the European Convention on Human Rights throughout Europe. The role of a Court such as ours, unless it were to depart from its intended mission, is not to be popular. Sometimes it is even necessary to cause displeasure. In the Europe of the Council of Europe, of which you are all representatives this evening, the rule of law must prevail and any discrimination must be excluded. Those two cases must serve as examples. It is noteworthy that those two judgments, in spite of their highly sensitive nature and any misunderstanding to which they may have given rise in public opinion, were executed so quickly. Is this not an illustration of that dialogue with States and with the highest national courts which goes to the heart of my message this evening? There is no question of pointing the finger at States which are not so rapid in their execution of our judgments. I would simply like to remind them that this system belongs to them; that it is our common system and that if we wish to preserve this common area of freedom, then the execution of judgments is an absolute necessity.

When looking back at the year 2013 to see what has been achieved in terms of dialogue, we should not forget our on-going dialogue with the European Union. On the one hand, it continues to be seen on the occasion of our various, and always constructive, meetings with the Court of Justice of the European Union, and for the first time in 2013 with the General Court, from which we were pleased to receive a delegation. But above all, we expect this dialogue to develop significantly with the European Union's accession to the European Convention on Human Rights. One year ago, in this very forum, I referred to this project with its aim of completing the European legal area of fundamental rights. I mentioned the technical difficulties which had arisen in the negotiations, stressing that they should not serve as a pretext for calling this noble endeavour into question.

I am therefore delighted that the agreement on the accession was finalised on 5 April 2013. Admittedly, before entering into force, a certain number of hurdles will still have to be overcome. The draft agreement nevertheless represents a milestone on the road to the European Union's accession to our Convention. It will one day make it possible for the acts of European Union institutions to be subjected to the same external scrutiny as that which is already exercised by the European Court of Human Rights in relation to the acts of State institutions. By acceding to the Convention and thus allowing external judicial review of its action, the European Union will be showing that, like its member States, it accepts that its acts should be bound by the same requirements of respect for fundamental rights as those which apply to the acts of each European State.

The accession cannot go ahead without a certain number of adjustments to the Convention in order to take account of the specific non-State nature of the European Union. However, it is apparent from the draft Accession Agreement that the negotiators have succeeded in maintaining the delicate balance between the specificities of the Convention and those of European Union law. Among the necessary adjustments there are two of particular importance: the creation of the so-called "corespondent" mechanism and the possibility of the "prior involvement" of the Court of Justice of the European Union. A new dialogue with the European Union institutions will evolve once the accession has taken place. One of the next steps in the process is the opinion to be given by the Court of Justice on the subject of the accession. I look forward with optimism to reading that opinion.

At this point of my remarks I cannot refrain from expressing my genuine anxiety and burning concern in respect of the tragic events that are unfolding before our eyes in one of our Member States.

Let me express, in the most solemn manner possible, my sincere hope that peace will be restored to Ukraine and that it will be based on the principles of democracy, human rights and the rule of law to which all Council of Europe nations have committed themselves.

As I was saying a moment ago, it was virtually impossible to select any particular Constitutional Court or Supreme Court decision referring to our case-law, as you have delivered so many. 
Allow me, however, as I draw to a close, to cite one example in honour of our guest this evening. In 2009 the Federal Constitutional Court in Karlsruhe was called upon to examine the constitutionality of a new law on "Lebenspartnerschaft" (civil union of same-sex couples). That legislation did not provide for a survivor's pension. The Constitutional Court thus found it incompatible with the German Constitution, referring to our Karner v. Austria judgment, on the grounds of unjustified discrimination based on sexual orientation.

\section{President Voßkuhle,}

That is one example of the dialogue that has been maintained between your prestigious Court and our own for several years now. We often deal with similar, or even identical, subject matter. Just last year, it was rather a coincidence that on the very day we were delivering our $X v$. Austria judgment, your Court was ruling on an almost identical question. I should also mention the well-known Von Hannover judgments on the protection of the right to one's image, emanating both from our Court and from yours. Initially we found a violation of the Convention because, in our view, the public did not have a legitimate interest in knowing where public figures were or how they behaved generally in their private lives. We considered that the German courts had not struck a fair balance between the competing interests. You subsequently modified your case-law in order to bring it into line with our own and, on two occasions in judgments concerning the same applicant, we then endorsed the position of the German courts.

If you would allow me to draw a comparison, I sometimes see our courts as the soloists in the Concerto for Two Violins in D minor of Johann Sebastian Bach. In that Concerto the two soloists are intertwined, sometimes alternating the melodic line, carrying different tunes and rhythms, yet ultimately - and this is the important point - joining together and combining to produce a particularly harmonious piece. What a splendid example of musical dialogue!

\section{President Voßkuhle, of the Federal Constitutional Court of Germany,}

Your presence here among us this evening is a great honour and indeed confirms the harmonious relationship that exists between our courts.

We would now invite you to take the floor. 


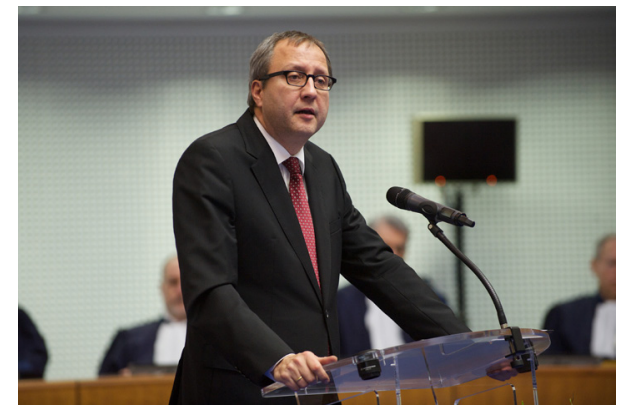

\title{
Prof. Dr. Andreas Voßkuhle
}

\author{
President of Bundesverfassungsgericht \\ Federal Constitutional Court, Germany
}

\section{Pyramid or Mobile? - Human Rights Protection} by the European Constitutional Courts

Mr President, Dear colleagues, Ladies and Gentlemen,

It is a true honour for me to join you today for the opening of the judicial year, and I thank you very much for the invitation to take part in this important occasion.

\section{A. INTRODUCTION}

The title of my speech is "Pyramid or Mobile? - Human Rights Protection by the European Constitutional Courts". Contrary to what the words "pyramid or mobile" might suggest, I am not going to talk about telecommunications in Egypt. By "mobile" I mean - taking my inspiration from the former judge Renate Jaeger - a kinetic sculpture which consists of an ensemble of balanced parts that can move but are connected by strings or wire. ' I use the word "pyramid" to refer to a fixed geometric structure that has a base and a top.

In the following paragraphs I will try to establish which of these two images more accurately captures the characteristics of the European constitutional courts in their protection of human rights. In order to do this we need to examine some features of the interaction of these courts and of their respective catalogues of rights. The system of human rights protection in Europe is a topic which I have already highlighted in past speeches. However, we will see that the Verbund is a living and changing organism whose constant evolution deserves to be observed, accompanied and rebalanced. In my speech, I will approach this very complex topic by making just a few brief observations.

\section{B. STRASBOURG AND KARLSRUHE: DIALOGUE - NOT ONE-WAY TRAFFIC}

\section{Ladies and Gentlemen,}

If you look at the parts of a mobile for some time, you will realise that they are not revolving around their own axes, but are constantly engaged in an imaginary dialogue triggered by the movements of the other parts. The ECtHR and the German Federal Constitutional Court (FCC) - like all national constitutional courts - also depend on a permanent dialogue in order to coordinate the protection of fundamental rights in a multi-level system.

How does the interplay between the European Convention on Human Rights and the German Constitution work? What concessions do the ECtHR and the FCC have to make in order to coordinate their work? Where might adjustments be necessary?

Let me ease the suspense: a strictly hierarchical - in other words, a pyramidal - approach would not fit the characteristics of a Verbund of European constitutional courts.

1 Interview in The Economist, 26 March 2009, p. 34. 


\section{THE ROLE OF THE FEDERAL CONSTITUTIONAL COURT}

First of all, let us examine the "mobile of institutions" from the point of view of the FCC. The Basic Law is not only open towards European and international law, it is also explicitly open towards human rights. Under the Basic Law the FCC, as well as all other constitutional bodies, must serve the cause of international human rights. Our recent case-law shows that these words are not mere constitutional rhetoric. In May 2011 , subsequent to your decision in M. v. Germany of December $2009^{2}$, the FCC delivered a judgment concerning preventive detention in Germany. ${ }^{3}$ Two aspects of this judgment prove the FCC's openness towards human rights. First, the FCC chose to apply the national procedural rules flexibly in order to avoid further breaches of the Convention. Notwithstanding a previous decision declaring the provisions on preventive detention constitutional - a situation which, under German law, generally acts as a procedural bar against the admissibility of new proceedings - the FCC found the new constitutional complaints admissible in the light of the decision in $M$. $v$. Germany. ${ }^{4}$ And secondly, the FCC stressed that the Convention has to be thoroughly considered at an early stage in the context of the constitutional system incorporating it. Although, in Germany, the European Convention on Human Rights does not have the same rank as the Constitution, it does have significance under our constitutional law. For the FCC, it is an important guide to interpretation when it comes to determining the content and scope of the fundamental rights and constitutional guarantees of the Basic Law.

As you can see, the FCC accepts guidance from Strasbourg and is able to remedy breaches of the Convention at national level - thereby helping to ease the caseload of the ECtHR. We are pleased that in the Kronfeldner ${ }^{5}$ case the ECHHR recently welcomed our approach consisting in interpreting the Basic Law in the light of the Convention, as this demonstrates the intensive dialogue between the two courts.

However, acceptance of the Convention should not be mistaken for strict obedience. The Basic Law has certain limits when it comes to its interpretation in the light of international law. The comparative interpretation has to be justifiable in terms of methods and compatible with the Basic Law's core values (Article $79 \S 3$ of the Basic Law $(G G)) .{ }^{6}$ In addition, the interpretation must not - in accordance with Article 53 of the Convention - compromise the standard of protection of fundamental rights provided by the Basic Law. ${ }^{7}$ Occasionally, the Basic Law guarantees a higher level of protection. This is illustrated by two recent judgments, one by the ECHHR and the other by the FCC, which were delivered on the same day. The ECtHR's judgment in X and Others v. Austria of 19 February 2013 concerned the right of unmarried same-sex couples to second-parent adoption, ${ }^{8}$ while the FCC's judgment concerned the bar on successive adoption by registered civil (same-sex) partners. ${ }^{9}$ Whereas the ECtHR held that there had been no violation of Article 14 in conjunction with Article 8 of the Convention when the applicants' situation was compared with that of a married couple, ${ }^{10}$ the FCC found that the bar on successive adoption by registered civil partners violated the general principle of equality before the law (Article $3 \S 1 \mathrm{GG}$ ). ${ }^{11}$

\section{THE ROLE OF THE EUROPEAN COURT OF HUMAN RIGHTS}

And what about the basis for cooperation on the part of the European Court of Human Rights? To my mind, the European Court of Human Rights is not a lone combatant either, but a strong team player. It does not render national constitutional courts unnecessary but takes their existence as a

2 M. v. Germany, no. 19359/04, ECHR 2009

3 Decisions of the Federal Constitutional Court (Entscheidungen des Bundesverfassungsgerichts - BVerfGE) $128,326<386>$.

4 See BVerfGE 128, $326<364>$ et seq.

5 Kronfeldner v. Germany, no. 21906/09, § 59, ECHR, 19 January 2012; see also B v. Germany, no. 61272/09, §§ 44 et seq. and § 98, 19 April 2012.

6 See BVerfGE, loc. cit., p. 371

7 See BVerfGE, loc. cit.

$8 X$ and Others v. Austria [GC], no. 19010/07, ECHR 2013.

9 BVerfGE, judgment of the First Division (Senat) of 19 February 2013, 1 BvL 1/11, NJW (Neue Juristische Wochenschriff) 2013 , p. 847.

$10 X$ and Others $v$. Austria [GC], ECHR, cited above, $\S \S 105$ et seq.

11 BVerfGE, judgment of the First Division (Senat) of 19 February 2013, 1 BvL 1/1 1, NJW 2013, p. 847 (855). 
precondition. To continue my image of the mobile of institutions: each element is necessary in order to maintain the balance. Otherwise, a single hanging object would orbit around itself.

In order to perform this balancing act the ECHHR, as an international court, is faced with the task of defining the minimum standard of fundamental rights protection. This minimum standard can be accepted by the national authorities and courts of all the member States without the plurality of national fundamental rights provisions being sacrificed. At the same time, when it comes to the effective enforcement and the dynamic evolution of the Convention, the ECtHR increases the level of acceptance by demonstrating respect for the national "heritage" - traditions that have evolved over a long time. The Grand Chamber judgment in Lautsi and Others v. Italy of 18 March 2011 is a fine example of judicial self-restraint. In the judgment, the Grand Chamber stated that the decision whether crucifixes should be present in classrooms was a matter falling within the margin of appreciation of the State Party concerned. Thus, it took into account the submissions of the Italian Government, which had argued that the presence of crucifixes in classrooms did not just have cultural significance but also contributed to the shaping of identity. ${ }^{12}$ Furthermore, the ECtHR, fortunately, respects the margin of appreciation where a case raises sensitive moral or ethical issues on which no consensus has been reached between the member States. One example in that regard is the case of Stübing, in which the ECtHR held that the applicant's conviction by the German courts for an incestuous relationship did not violate Article 8 of the Convention. Nor should we forget the Countryside Alliance case, in which the ECtHR decided that the various bans on fox hunting and the hunting of other wild mammals with dogs in the United Kingdom did not amount to a violation of the Convention. ${ }^{13}$ Even Lord Bingham's very, well, British argument to justify the ban, namely the suggestion, I quote, "that the British mind more about their animals than their children ${ }^{14 "}$, was apparently regarded as falling within the margin of appreciation. ${ }^{15}$

As you know, the Council of Europe has, in the meantime, presented Protocol No. 15 to the Convention, which incorporates into the preamble a reference to the principle of subsidiarity and the doctrine of the margin of appreciation. ${ }^{16}$ This is a major contribution to the rebalancing of our mobile of institutions. The more the implementation of the Convention is devolved to the national authorities and courts, the better the ECHHR - in view of its limited resources - can focus on its role as the guardian of a common core standard of human rights. At the same time, as my Belgian colleague Bossuyt recently pointed out, some questions - especially those concerning positive obligations - are best left to the domestic courts, which are familiar with the national community's economic, social and cultural environment. ${ }^{17}$ Extending the Court's jurisdiction to economic and social rights beyond a core standard could deprive human rights of their universality, since the above-mentioned rights are unattainable by many countries. ${ }^{18}$

\section{STRASBOURG AND LUXEMBOURG: THINGS GET MOVING}

Strasbourg is not only intimately connected with the national courts. It is also closely linked with the other European court, the European Court of Justice (ECJ) in Luxembourg - linked in a way we could describe as a "relationship in motion". In this relationship, the representative of a national constitutional court is, of course, not a direct protagonist. Nonetheless, pursuing the logic of the mobile image, any movement by other elements of the mobile necessarily has repercussions on the system as a whole. Thus, the national courts are more than just casual bystanders. So, from the viewpoint of an interested observer, I will briefly identify three ties between the two courts that already exist or are about to emerge.

12 Lautsi and Others v. Italy [GC], no. 30814/06, §§ 67 et seq., ECHR 2011 (extracts).

13 Friend and Countryside Alliance and Others v. the United Kingdom (dec.), nos. 16072/06 and 27809/08, ECHR, 24 November 2009.

$14 R$ (Countryside Alliance) v. Attorney General [2008] 1 AC 719, para 37.

15 See Hale, "Argentoratum Locutum: Is Strasbourg or the Supreme Court Supreme?", H.R.L.R. 12 (2012), p. 65 (72).

16 Article 1 of Protocol No. 15 amending the Convention for the Protection of Human Rights and Fundamental Freedoms.

17 Bossuyt, "Judicial activism in Strasbourg", to appear in print, manuscript p. 17.

18 lbid., manuscript p. 17 


\section{THE DOSE MAKES THE POISON: MUTUAL REFERENCES IN THE JUDGMENTS OF THE ECJ AND THE ECTHR}

The first thing that seems remarkable to me is the way in which the Luxembourg and Strasbourg courts make use of each other's frame of reference. To draw upon other human rights texts and case-law sources is, of course, an excellent way to achieve the necessary consistency between overlapping human rights catalogues. But, as always, the dose can make what is normally a remedy into a poison. In mutual references to the relevant texts there are certain pitfalls to be avoided. It would be inappropriate for the Strasbourg Court to aim to be the first in shaping the interpretation of a Charter provision. The same would apply if the Luxembourg Court were to rely on the Convention in order to override the restricted scope of application of the Charter. Luckily, these pitfalls appear largely theoretical. Recently, some scholars criticised what they saw as a significant decrease in the ECJ's citation of the Convention text and case-law, and cautioned against an isolated interpretation of the Charter. ${ }^{19}$ My personal guess would be that with the accession of the EU to the Convention, the convergence between the human rights instruments will increase again.

\section{II. ÅKERBERG FRANSSON: THE COURTS AS NEIGHBOURS, NOT TWINS}

Secondly and even more remarkably, a certain rapprochement can be observed between the roles of the two Courts.

To put it in a nutshell using the words of a Law professor, the Luxembourg Court has "evolved from being a tribunal concerned primarily with economic matters, to one with a much wider range of jurisdiction which is now explicitly tasked with enforcing human rights". ${ }^{20}$ This shift in its nature, of course, raises new questions as to the respective functions of the Strasbourg and Luxembourg Courts. As I see it, the mandates of the two Courts should not blur, but be kept quite distinct. Whereas Strasbourg, in accordance with Article 53 of the Convention, sets the minimum level of human rights protection throughout Europe, the ECJ must ensure that the law is observed in the interpretation and application of the EU Treaties (Article $19 \S 1$ of the Treaty on European Union). Recently, the Åkerberg Fransson decision ${ }^{21}$ swept like a blast - or even a storm - through the mobile I have described. In the aftermath of Akerberg, it is perhaps important to stress the following: as much as a uniformly high human rights standard in Europe is desirable, it is not the task of the Luxembourg Court, but that of Strasbourg and the ECHHR, to safeguard it internationally.

\section{SAVE THE LAST DANCE FOR STRASBOURG?}

Thirdly and finally, the most striking of the ongoing transformations is the emerging formalisation of the relationship between the two Courts.

The accession of the EU to the Convention will reshape the institutional architecture. European laws and judgments will be subject to the jurisdiction of the Strasbourg Court - an operation which our host, the President of the ECtHR Dean Spielmann, rightly praises as a high point of modern Europe's commitment to human rights. ${ }^{22}$ For accession to operate smoothly, it might once more be helpful to set the pyramid model aside and to focus on the mobile instead. Becoming part of the Convention should not be thought of in terms of hierarchy, but in terms of specialisation. Strasbourg will not acquire the authority to assess the validity or the correct interpretation of EU law in a binding

19 De Búrca (2013), "After the EU Charter of Fundamental Rights: The Court of Justice as a Human Rights Adjudicator?", Maastricht Journal of European and Comparative Law 20, p. 168 (173-176); Polakiewicz, "EU law and the ECHR: Will the European Union's Accession Square the Circle?", E.H.R.L.R, p. 592 (594 -597).

20 De Búrca (2013), "After the EU Charter of Fundamental Rights: The Court of Justice as a Human Rights Adjudicator?", Maastricht Journal of European and Comparative Law 20, p. 168 (171).

21 ECJ (Grand Chamber), judgment of 26 February 2013, C-617/13 - Ákerberg Fransson.

22 D. Spielmann, "Krönung des Engagements des modernen Europas für die Menschenrechte", Menschenrechte in Europa, Speech to the Bundesverfassungsgericht on 9 April 2013. 
manner. ${ }^{23}$ Instead, accession means no more - and no less - than the external involvement of a specialised international human rights court. An involvement that will enhance the legitimacy and credibility of the system of human rights protection as a whole.

\section{CONCLUSION}

Ladies and Gentlemen, we have seen that European human rights protection can be better understood if we imagine it not as a pyramid, but as a mobile. We have also established that a mobile, in order to work, quite literally comes with strings attached. The parts of the system (we, the European Constitutional Courts) have to go about their task with sensitivity in order to preserve the balance. After all, we do not want the mobile and its strings to turn into a spider's web in which those who seek protection get entangled.

There is a citation by Alexander Calder, the father of the mobile as an art medium. He noted that "when everything goes right, a mobile is a piece of poetry that dances with the joy of life and surprises." I think even the visionary drafters of our respective human rights catalogues would be surprised by how dynamic the multi-level human rights protection in Europe has proved to be. As far as dancing is concerned, this might not be compatible with the character of a solemn hearing. But I am very much looking forward to interesting, animated and fruitful exchanges with you tonight and in the future.

Thank you very much for your attention.

23 See A. Torres Pérez (2013), "Too many voices? The prior involvement of the Court of Justice of the European Union", European Journal of Human Rights 4, p. 565 (583). 


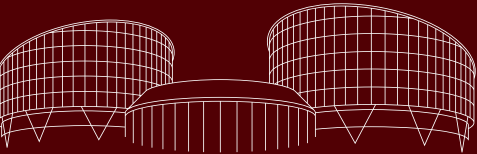

www.echr.coe.int 